\title{
Formation of corrensite, chlorite and chlorite-mica stacks by replacement of detrital biotite in low-grade pelitic rocks
}

\author{
WEI-TEH JIANG* AND DONALD R. PEACOR \\ Department of Geological Sciences, The University of Michigan, Ann Arbor, MI 48109-1063, USA
}

ABSTRACT Transmission and scanning electron microscopy were utilized to investigate the nature and mechanisms of alteration of abundant detrital biotite of volcanic origin and progressive modification of phyllosilicate aggregates in a prograde sequence of pelitic rocks (illite crystallinity index $=0.19-0.58^{\circ} \Delta 2 \theta$ ) from the Gaspé Peninsula in Quebec.

Detrital biotite has been diagenetically altered to form corrensite and chlorite through two mechanisms; (1) layer-by-layer replacement gave rise to interstratification of packets of layers and complex mixed layering via several kinds of layer transitions between biotite and chlorite, corrensite or smectite; (2) dissolution-transport-precipitation resulted in the formation of relatively coarse-grained aggregates of randomly orientated, corrensite-rich flakes and fine-grained corrensite intergrown with chlorite and illite in the matrix.

The data show that stacks consisting of alternating packets of trioctahedral and dioctahedral phyllosilicates originated during early diagenesis when lenticular fissures in strained altering biotite were filled by dioctahedral clays. Subsequent prograde evolution of dioctahedral clays occurred through deformation, dissolution and crystallization, and overgrowth. Illite evolved to muscovite, with $\mathrm{K}$ in part provided through biotite alteration, and corrensite/chlorite to homogeneous chlorite. The alteration of detrital biotite is closely related to the formation of titanite and magnetite in diagenetic rocks, and pyrite, calcite and anatase or rutile in the higher grade rocks.

The observations demonstrate that detrital biotite of volcanic origin may be the principal precursor of chlorite in chlorite-rich metapelites originating in marginal basins. The mineral parageneses suggest that the transitions from corrensite to chlorite and illite to muscovite may be a function of local chemistry and time.

Key words: chlorite-mica stacks; corrensite; Gaspé, Canada; low-grade pelites.

\section{INTRODUCTION}

Alteration of detrital biotite during diagenesis has been observed or inferred to occur in many sedimentary and metasedimentary rocks (Weaver, 1984; White et al., 1985; AIDahan \& Morad, 1986; Dimberline, 1986; Morad, 1986; Morad \& AlDahan, 1986; Beaufort, 1987; Claeys \& Mount, 1991; Milodowski \& Zalasiewicz, 1991; Li et al., 1994). Common alteration products are chlorite, illite (or phengite and muscovite) and kaolinite. Smectite and related mixed-layer minerals have only rarely been inferred to occur as precursor phases of chlorite and illite during such alteration (e.g. Dimberline, 1986; Beaufort, 1987; Milodowski \& Zalasiewicz, 1991; Li et al., 1994). Previous studies of the diagenetic alteration of detrital biotite were based on X-ray powder diffraction (XRD), electron microprobe analyses and optical and scanning electron microscopic data from which alteration mechanisms were only indirectly inferred.

\footnotetext{
* Present address: Department of Earth Sciences, National Cheng Kung University, Tainan 70101, Taiwan.
}

Chlorite-mica stacks consist of parallel or subparallel packets of chlorite and muscovite (or illite and phengite) that are much more coarse grained than matrix minerals and occur commonly in metapelites. They typically display deformation features that imply an origin preceding or contemporaneous with tectonic deformation (e.g. Beutner, 1978; White \& Knipe, 1978; Weber, 1981; Craig et al., 1982; van der Pluijm \& Kaars-Sijpesteijn, 1984; Woodland, 1985; Dimberline, 1986; Gregg, 1986; Milodowski \& Zalasiewicz, 1991; Li et al., 1994). One of the proposed origins of such chlorite-mica intergrowths is related to diagenetic alteration of detrital biotite (e.g. Weaver, 1984; Dimberline, 1986; Roberts \& Merriman, 1990; Li et al., 1994). Direct observations of remnants of detrital biotite that are partially replaced by chlorite and phengite were made primarily on sandstones (e.g. Morad, 1986; Claeys \& Mount, 1991); these differ from pelitic rocks in that the other minerals commonly are as coarse grained as the phyllosilicate stacks. Detrital biotite occurring in mudstones, shales or slates has only rarely been studied (Weaver, 1984; White et al., 1985; Roberts \& Merriman, 1990 ), probably because the alteration products commonly consist of mixtures that are not resolvable by optical 
methods and scanning electron microscopy (SEM) Detailed study utilizing high-resolution transmission and analytical electron microscopy (TEM and AEM) therefore is essential to an understanding of alteration processes of detrital biotite and the formation of chlorite-mica stacks.

The diagenetic and metamorphic evolution of corrensite and chlorite in a prograde sequence of pelitic rocks from the Gaspé Peninsula in Quebec was reported by Jiang \& Peacor (1994). They briefly described the occurrences of detrital biotite in the diagenetic rocks and large chlorite-mica stacks in the anchizonal and epizonal rocks, but the prograde alteration processes of those materials were not evaluated. This paper describes the SEM, TEM and AEM data obtained on the same sequence of samples, focusing on the nature and mechanisms of the alteration of detrital biotite, the formation and development of chlorite-mica stacks and the implication of mineral paragenesis.

\section{MATERIALS AND METHODS}

\section{Samples}

Five samples were selected from a prograde sequence of pelitic rocks along the northern coast of the Gaspé Peninsula, Quebec. Detailed sample localities and descriptions are given by Jiang \& Peacor (1994). The samples represent deep-water sediments of the Ordovician Deslandes and Cloridorme formations deposited in a foreland basin created by the collision of a late Cambrian to early Ordovician island-arc system with the early Palaeozoic North American continent (St. Julien \& Hubert, 1975). The rocks are part of a Taconic imbricate thrust system. Utilizing clay mineralogy, vitrinite reflectance, homogenization temperature of fluid inclusions and conodont colour index, Hesse \& Dalton (1991) described a northward pattern of increasing metamorphic grade primarily caused by tectonic overburden and heating, and a zonal increase in the grade of thermal alteration toward a Devonian pluton in the sampled area. Samples A419, A416, R299, 89-12 and R245 have illite crystallinity indices of $0.58,0.45,0.31,0.27$ and $0.19^{\circ} \Delta 2 \theta$ (ethylene-glycolsolvated), respectively, where 0.38 and $0.21^{\circ} \Delta 2 \theta$ are the limits for the anchizone (Kisch, 1990).

The definition of foliation increases with metamorphic grade; a foliation defining a weak cleavage is parallel or subparallel to bedding in the lower grade rocks and a strong spaced cleavage is subnormal to bedding in the epizonal rocks (Jiang \& Peacor, 1994). These relations are consistent with a tectonically induced prograde sequence as inferred by Hesse \& Dalton (1991).

\section{Previous mineralogical studies}

Prograde changes of the matrix minerals of nine pelitic rocks from the same sequence of rocks studied here were previously studied by Jiang (1993) and Jiang \& Peacor (1994) using TEM, SEM, petrographic microscopy and $\mathrm{X}$-ray powder diffraction (XRD) methods. Mixed-layer chlorite/smectite $(\mathrm{C} / \mathrm{S})$ that has $\mathrm{R} 1$ ordering (corrensite) and coexists with chlorite and illite (interstratified with minor dioctahedral smectite) in the diagenetic rocks was identified based on the positions and relative displacements of the $00 l$ reflections in XRD patterns of air-dried, ethylene-glycol-solvated and oven-heated (at c. $375^{\circ} \mathrm{C}$ ) $<2$ $\mu \mathrm{m}$ fractions. Jiang \& Peacor (1994) suggested that the slightly asymmetrical c. $10-\AA$ reflections in XRD patterns of the air-dried $<2-\mu \mathrm{m}$ fractions of diagenetic rocks arose from illite associated with minor interstratified dioctahedral smectite instead of mixed layers involving detrital biotite because only a few biotite grains were observed in clay separates by TEM. No evidence was observed for the occurrence of mixed-layer biotite/chlorite, biotite/ vermiculite or chlorite/vermiculite.

The diagenetic $\mathrm{C} / \mathrm{S}$ was estimated to have c. $60 \%$ chlorite by comparison with the empirical and calculated results of Moore \& Reynolds (1989). Jiang \& Peacor (1994) showed that the amount of $\mathrm{C} / \mathrm{S}$ diminishes significantly from the zone of diagenesis to the anchizone and is absent in the epizone, concomitant with an increase in the abundance of chlorite. The diagenetic illite, chlorite and $\mathrm{C} / \mathrm{S}$ were inferred to be the precursors of the muscovite and chlorite occurring in the higher grade rocks.

\section{Experimental techniques}

Carbon-coated, ion-milled TEM specimens were prepared following the procedures described in Jiang \& Peacor (1994). Petrographic relations of minerals shown here were obtained largely on TEM specimens with back-scattered electron (BSE) imaging techniques, utilizing a Hitachi S-570 scanning electron microscope (operated at $15 \mathrm{kv}$ ) fitted with a BSE detector and a Kevex Quantum X-ray energy-dispersive spectroscopic (EDS) system. Contrast differences in BSE images primarily reflect variations in average atomic density of phases as usual, but with local contrast arising from surface relief generated during the ion-milling process. A Philips CM12 scanning transmission electron miscoscope coupled with a low-angle Kevex Quantum detector for EDS analysis was operated at $120 \mathrm{kV}$ for TEM imaging, selected-area electron diffraction (SAED) and AEM analyses. The instrumental settings were given by Jiang (1993) and references therein.

\section{Criteria for the identification of interstratified chlorite/smectite and biotite/chlorite}

Major minerals including chlorite, $\mathrm{C} / \mathrm{S}$, illite, quartz, albite and calcite were identified primarily on the basis of SEM observations, including textural relations and EDS spectra, optical properties, and the XRD data given by Jiang \& Peacor (1994). In particular, portions of samples in BSE images that displayed curved phyllosilicate-like flakes that gave EDS spectra and optical properties analogous to those of C/S or corrensite (Shau et al., 1990) and exhibited microcracks due to dehydration in the SEM vacuum were identified as $\mathrm{C} / \mathrm{S}$-rich materials (Figs $1 \& 2$ ). Identification of minor phases including plagioclase, 
potassium feldspar, apatite, iron oxides and sulphides, and $\mathrm{TiO}_{2}$ minerals was then mainly based on EDS spectra and SAED patterns.

Some fine-grained clays gave TEM images that consist of $14-\AA / 10-\AA ̊$ mixed layers with abundant structural defects including layer terminations and having wavy layers resembling smectitic materials, EDS spectra characteristic of $\mathrm{C} / \mathrm{S}$ and diffuse reflections in SAED patterns. Such materials were identified as $\mathrm{C} / \mathrm{S}$, as these features are characteristic of dehydrated $\mathrm{C} / \mathrm{S}$ as observed by TEM (e.g. Shau et al., 1990; Bettison-Varga et al., 1991) and that identification is consistent with XRD observations (Jiang \& Peacor, 1994).

Although the XRD and TEM data of Jiang \& Peacor (1994) led to identification of $\mathrm{C} / \mathrm{S}$ rather than biotitevermiculite or other types of mixed layers, local variations may have occurred, especially in altered biotite grains of the diagenetic rocks described below. The high-quality powder XRD data required for further characterization of such small, complex materials could not be obtained, as coarse-grained biotite only occupies a small volume of the relatively silty layers of the diagenetic rocks and biotite in the clay-rich portions is too fine-grained and cannot be separated from other clays.

Distinction between chlorite-smectite or biotitevermiculite mixed layers based on 001 lattice fringes alone is ambiguous because vermiculite lattice fringes may have c. 10 or c. $14-\AA$ spacings (Banfield \& Eggleton, 1988; Vali \& Hesse, 1992, and references therein). However, our AEM analyses of packets of $10-\AA / 14-\AA$ mixed layers that are interstratified with relict biotite layers and display wavy lattice fringes characteristic of smectitic materials invariably gave a composition resembling that of the authigenic $\mathrm{C} / \mathrm{S}$ occurring in the fine-grained matrix. Such materials are therefore identified as $\mathrm{C} / \mathrm{S}$. In areas where only mixtures could be analysed, $\mathrm{C} / \mathrm{S}$ was distinguished from mixed-layer biotite/chlorite by the presence of equally significant amounts of $\mathrm{Ca}, \mathrm{Na}$ and $\mathrm{K}$ in $\mathrm{C} / \mathrm{S}$ and relatively high $\mathrm{K}$ and $\mathrm{Ti}$ in biotite/chlorite. Here we consider the latter being mixed-layer biotite/chlorite instead of biotite/vermiculite because packets of c. $14-\AA$ layers that are interstratified with or directly adjacent to relict biotite packets were shown to be chlorite by EDS analyses and the composition of the mixed layers is approximately intermediate between those of the chlorite and biotite.

\section{DIAGENETIC ALTERATION OF DETRITAL BIOTITE \\ Petrographic observations}

Sample A416 from the diagenetic zone is a mudstone with some relatively silty layers up to $c .1 \mathrm{~mm}$ thick. The mudstone is dominated by quartz, albite and fine-grained clay minerals including chlorite, illite, $\mathrm{C} / \mathrm{S}$, minor berthierine and possibly some illite-rich mixed-layer illite/smectite (I/S) in the matrix. It also contains relatively coarse-grained detrital biotite as seen in SEM images (Fig.

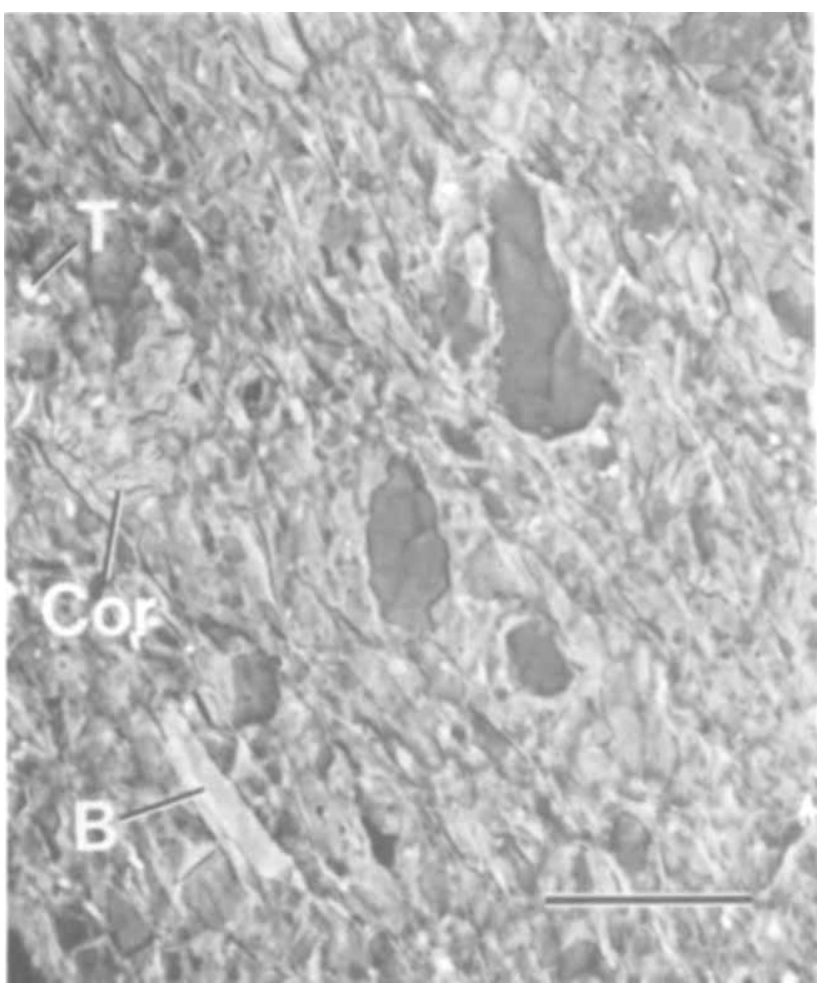

Fig. 1. Back-scattered electron image of mudstone sample A416 from the diagenetic zone of the Gaspé Peninsula. B, biotite; Cor. corrensite; $\mathrm{T}$, titanite. Other minerals include quartz and albite (dark grey, irregular grains), and the principal matrix minerals are very fine-grained illite, corrensite and chlorite. Scale bar $=20 \mu \mathrm{m}$.

1). The biotite often has minor $\mathrm{Ca}$ and $\mathrm{Na}$ contents and abnormally low $\mathrm{K}$ contents relative to normal biotite, implying partial alteration. Corrensite occurs ubiquitously in the matrix but occasionally is concentrated in small areas consisting of randomly orientated flakes and displaying irregular microcracks (Fig. 1) caused by dehydration. Such corrensite-rich aggregates are larger in the relatively silty layers, often associated with titanite and/or single grains or framboidal aggregates of magnetite, having interlocking textures with other phases (Fig. 2a).

Each grain forming the magnetite framboids has a cubic cross-section resembling that of pyrite but gives a series of continuous rings in SAED patterns (not shown) characteristic of polycrystalline materials. Such framboidal grains were probably formed by pseudomorphic replacement of pyrite framboids that formed in early diagensis, an origin also suggested by Suk et al. (1990) for magnetite in the Lower Ordovician limestones from Tennessee. However, discrete magnetite grains were also observed to occur with largely altered biotite (Fig. 2b), implying that some of the magnetite may have been a by-product of biotite alteration.

Biotite grains in the silty layers are coarser grained than those in clay-rich layers and vary from nearly unaltered to nearly completely altered but with unaltered remnants 

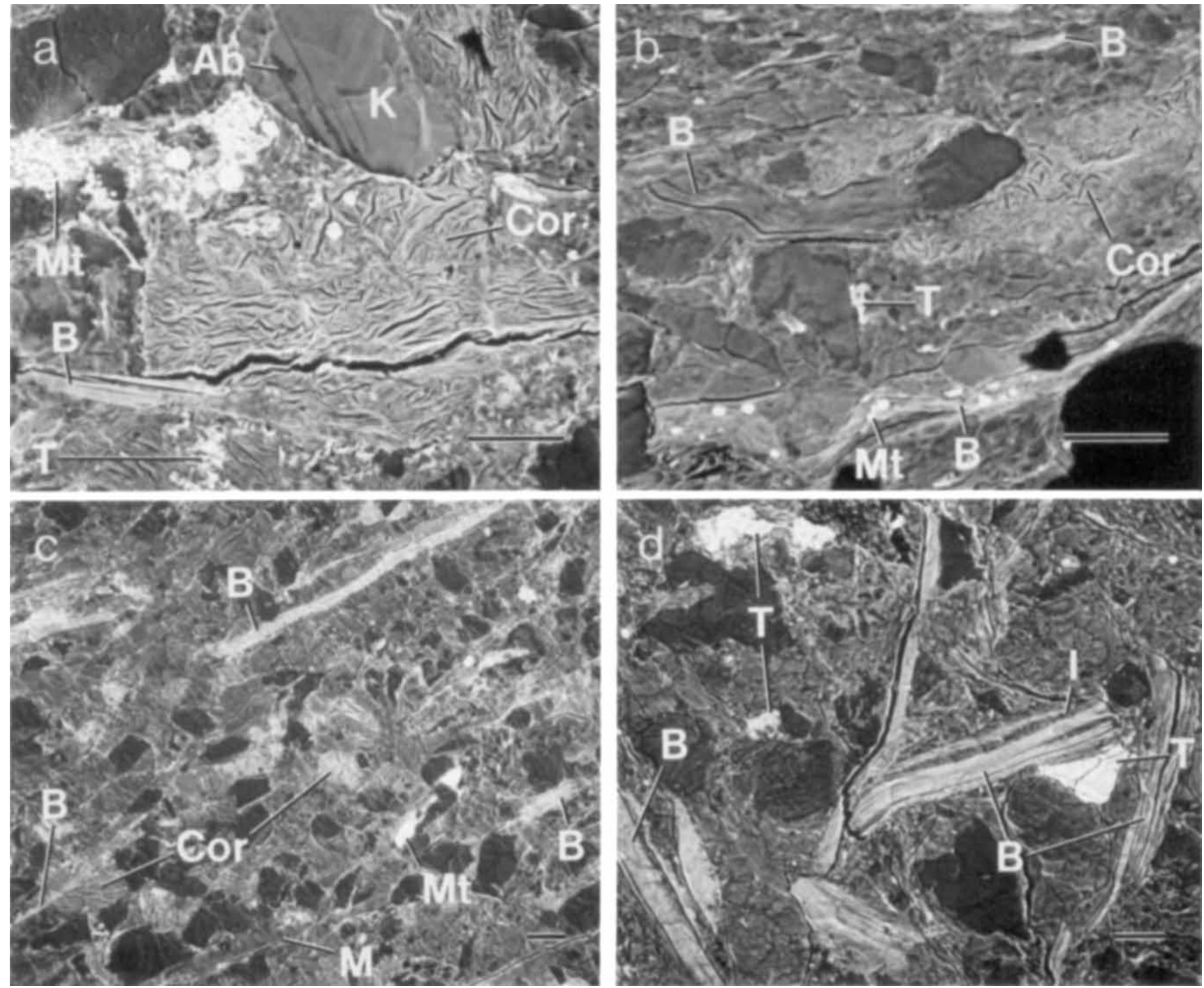

Fig. 2. Back-scattered electron images of the relatively silty layers in sample A416 showing: (a) aggregates of corrensite-dominated flakes coexisting with partially altered detrital biotite (B), albitized potassium feldspar ( $\mathrm{Ab}$ and $\mathrm{K}$ ), magnetite framboids (Mt), titanite (T) and quartz (dark grey, irregular grains); (b) largely altered detrital biotite associated with single grains of magnetite and titanite; (c) relatively unaltered and undeformed detrital biotite and muscovite, and partially altered biotite merged in a corrensite-rich aggregate; and (d) lenticular phengitic illite sandwiched by deformed detrital biotite. Scale bars $=20 \mu \mathrm{m}$.

(Fig. 2). Some of the partially altered biotite grains are directly adjacent to or enclosed in corrensite-rich aggregates with irregular but well-defined boundaries (e.g. Fig. 2a,c). Some of the altered detrital biotite grains have lenticular fissures filled with white mica, some of which is deformed with the host biotite (Fig. 2d). In contrast, unaltered biotite grains do not contain any intercalated white mica (Fig. 2c). The white mica is phengitic $1 M_{\mathrm{d}}$ illite displaying relatively perfect lattice fringes (Fig. 3) unlike many defect-rich illitic crystals in the matrix. It has a composition very different from that of detrital muscovite (Table 1), e.g. it is $\mathrm{K}$ - and Al-poor, implying a diagenetic origin. Albitization is also a prominent diagenetic feature in the studied samples, albite being a major mineral occurring as a replacement of Ca-bearing plagioclase and potassium feldspar (Fig. 2a). In addition, it locally occurs as euhedral crystals that imply direct precipitation from pore fluids.

\section{Transmission and analytical electron microscopic data}

Corrensite-rich aggregates are dominated by alternating chlorite $c$. $14-\AA$ and collapsed smectite $c .10-\AA$ layers, but occurrences of successive chlorite and smectite layers are not uncommon (Fig. 4a,d). Smectite and corrensite layers are wavy and terminations of smectite layers or corrensite units by chlorite layers are common in such aggregates. SAED patterns of corrensite-rich grains show rather diffuse $00 l$ reflections having a periodicity of c. $24 \AA$ in 


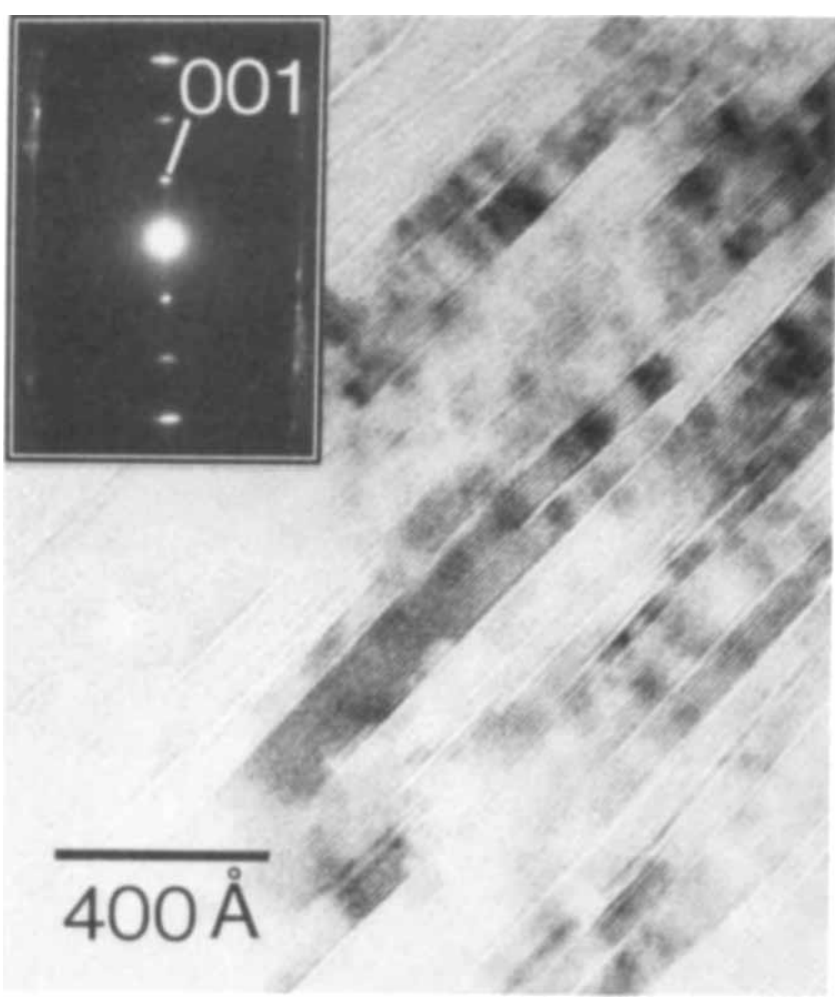

Fig. 3. Lattice-fringe image and electron diffraction pattern of phengitic illite in a lenticular fissure sandwiched by detrital biotite in diagenetic sample A416. The lattice fringes have a spacing of $c .10 \AA$ and the 001 reflection has a $d$-value of $c .10 \AA$. The $02 l$ reflection row (or its pseudohexagonal equivalent) has significant streaking.

association with streaking along $c^{*}$, implying locally disordered mixed-layer sequences (Fig. 4b).

The AEM analyses of such regions (Table 2) gave a composition typical of corrensite or $\mathrm{C} / \mathrm{S}$ except for the $\mathrm{K}$ content. Although the proportion of interlayer $\mathrm{K}$ of $\mathrm{C} / \mathrm{S}$ from most metabasites and hydrothermally altered volcanogenic rocks is small (e.g. Inoue, 1985; Shau et al., 1990; Meunier et al., 1991; Robinson et al., 1993), it is a major component of $\mathrm{C} / \mathrm{S}$ in the Gaspé rocks as well as in many other rock sequences (e.g. Brigatti \& Poppi, 1984; Bettison \& Schiffman, 1988; Bettison-Varga et al., 1991; Shau \& Peacor, 1992). Some of this material locally exhibited severe layer distortions and separations (Fig. 4c) due to uneven contraction or expansion, reflecting structural and/or chemical heterogeneity.

The detrital biotite has signficant $\mathrm{Ti}$ but no detectable $\mathrm{Ca}$ and $\mathrm{Na}$ (Table 2). Slightly altered biotite invariably has less $\mathrm{Ti}$ and $\mathrm{K}$, more $\mathrm{Ca}$ and $\mathrm{Na}$, and a higher $\mathrm{Mg} /(\mathrm{Fe}+\mathrm{Mg})$ ratio. Interlamination of packets of biotite, chlorite and $\mathrm{C} / \mathrm{S}$ associated with layer terminations is one of the common features in altered biotite grains observed in SEM images. In Fig. 5, three layers of a biotite packet that is sandwiched by $\mathrm{C} / \mathrm{S}$ and chlorite terminate against two chlorite layers. Above that biotite packet, some relatively straight $c .10-\AA$ layers are interstratified with c. $14-\AA$ layers; $\mathrm{AEM}$ analyses show minor $\mathrm{Ca}$ and $\mathrm{Na}$ but
Table 1. Selected analytical electron microscope analyses of white mica in pelitic rocks from the Gaspé Peninsula. ${ }^{*}+\ddagger$

\begin{tabular}{|c|c|c|c|c|c|c|c|c|c|}
\hline \multirow[t]{2}{*}{$\begin{array}{c}\text { Sample } \\
\text { IC\& }\end{array}$} & \multicolumn{3}{|c|}{$\begin{array}{c}\mathrm{A} 416 \\
0.45^{\circ} \Delta 2 \theta\end{array}$} & \multicolumn{2}{|c|}{$\begin{array}{c}\text { R299 } \\
0.31^{\circ} \Delta 2 \theta\end{array}$} & \multicolumn{2}{|c|}{$\begin{array}{c}89.12 \\
0.27^{\circ} \Delta 2 \theta\end{array}$} & \multicolumn{2}{|c|}{$\begin{array}{c}\mathbf{R} 245 \\
0.19^{\circ} \Delta 2 \theta\end{array}$} \\
\hline & 1 & 2 & 3 & 4 & 5 & 6 & 7 & 8 & 9 \\
\hline $\mathrm{Si}$ & 3.08 & 3.44 & 3.37 & 3.04 & 3.40 & 3.15 & 3.35 & 3.05 & 3.26 \\
\hline Al & 0.92 & 0.56 & 0.63 & 0.96 & 0.60 & 0.85 & 0.65 & 0.95 & 0.74 \\
\hline Al & 1.91 & 1.53 & 1.72 & 1.79 & 1.65 & 1.69 & 1.71 & 1.48 & 1.63 \\
\hline Mg & 0.03 & 0.29 & 0.13 & 0.05 & 0.22 & 0.12 & 0.18 & 0.15 & 0.26 \\
\hline $\mathrm{Fe}$ & 0.06 & 0.18 & 0.15 & 0.16 & 0.11 & 0.17 & 0.11 & 0.30 & 0.09 \\
\hline Mn & 0 & 0 & 0 & 0 & 0 & 0 & 0 & 0 & 0 \\
\hline $\mathrm{Ti}$ & 0 & 0 & 0 & 0 & 0.02 & 0.02 & 0 & 0.07 & 0.02 \\
\hline K & 0.83 & 0.69 & 0.68 & 0.89 & 0.65 & 0.77 & 0.65 & 0.95 & 0.71 \\
\hline $\mathrm{Na}$ & 0.04 & 0.03 & 0.04 & 0.13 & 0 & 0.05 & 0 & 0 & 0.03 \\
\hline $\mathrm{Ca}$ & 0 & 0.01 & 0 & 0 & 0 & 0 & 0 & 0 & 0 \\
\hline $\begin{array}{l}\text { Interlayer } \\
\text { charge }\end{array}$ & 0.95 & 0.85 & 0.76 & 1.01 & 0.80 & 0.95 & 0.83 & 1.03 & 0.98 \\
\hline $\mathrm{Fe} /(\mathrm{Mg}+\mathrm{Fe})$ & 0.67 & 0.38 & 0.54 & 0.76 & 0.33 & 0.59 & 0.38 & 0.67 & 0.26 \\
\hline $\mathbf{A l} /(\mathbf{S i}+\mathbf{A} \mathbf{l})$ & 0.48 & 0.38 & 0.41 & 0.47 & 0.40 & 0.45 & 0.41 & 0.44 & 0.42 \\
\hline $\mathrm{SiO}_{2}$ & 47.35 & 53.36 & 52.31 & 45.87 & 53.30 & 48.42 & 52.60 & 45.69 & 50.87 \\
\hline $\mathrm{Al}_{2} \mathrm{O}_{3}$ & 36.92 & $27.5 \mathrm{l}$ & 30.95 & 35.20 & 29.92 & 33.13 & 31.44 & 30.88 & 31.38 \\
\hline $\mathrm{MgO}$ & 0.31 & 3.02 & 1.35 & 0.51 & 2.31 & 1.24 & 1.90 & 1.51 & 2.72 \\
\hline $\mathrm{FeO}$ & 1.10 & 3.34 & 2.78 & 2.89 & 2.06 & 3.12 & 2.07 & 5.37 & 1.68 \\
\hline $\mathrm{MnO}$ & 0 & 0 & 0 & 0 & 0 & 0 & 0 & 0 & 0 \\
\hline $\mathrm{TiO}_{2}$ & 0 & 0 & 0 & 0 & 0.41 & 0.41 & 0 & 1.39 & 0.42 \\
\hline $\mathrm{K}_{2} \mathrm{O}$ & 10.00 & 8.39 & 8.28 & 10.53 & 7.99 & 9.28 & 8.00 & 11.16 & 8.69 \\
\hline $\mathrm{Na}_{2} \mathrm{O}$ & 0.32 & 0.24 & 0.32 & 1.01 & 0 & 0.40 & 0 & 0 & 0.24 \\
\hline $\mathrm{CaO}$ & 0 & 0.14 & 0 & 0 & 0 & 0 & 0 & 0 & 0 \\
\hline
\end{tabular}

- Normalization is based on 6 octahedral and tetrahedral carions and all Fe is assumed to be ferrous. Oxide weight percents are determined by calculation assuming a total of 96 wt\%. + Two standard deviations on the basis of counting statistics are 0.08-0.14 per formula unit (pfu) for $\mathrm{Si}, 0.10-0.15 \mathrm{pfu}$ for $\mathrm{Al}, 0.01-0.04 \mathrm{pfu}$ for $\mathrm{Mg}$ and $\mathrm{Fe}$, 0.04-0.08 pfu for $\mathrm{K}$ and $\leq 0.02 \mathrm{pfu}$ for $\mathrm{Na}$ and $\leq 0.01$ for $\mathrm{Ca}, \mathrm{Mn}$ and $\mathrm{Ti}$. ‡Analysis $1=$ detrital muscovite; $2,4,6,8=$ white mica in phyllosilicate stacks: $3,5,7,9=$ white mica in matrix. $\$ \mathrm{IC}=$ illite crystallinity index.

with relatively high $\mathrm{Ti}$ and $\mathrm{K}$ contents compared with corrensite, implying that some of the layers are relict biotite. Conversion of a $c .10-\AA$ layer to a chlorite layer occurs in that region. In the lower left, the $14-\AA / 10-\AA$ mixed layers are wavy and have a corrensite-like composition with no or very little $\mathrm{Ti}$, suggesting that the area is dominated by corrensite or $\mathrm{C} / \mathrm{S}$. The SAED pattern (Fig. 5b) displays three parallel sets of $00 l$ reflections corresponding to chlorite, biotite and corrensite, respectively. Two other along-layer types of interfaces occur in altered biotite grains, including conversion of a single biotite layer to a $c .14-\AA$ layer plus a $c .10-\AA$ layer constituting a corrensite-like layer (Fig. 5c) and terminations of biotite by chlorite in several successive layers (Fig. $5 d$ ), forming a mineral interface slightly oblique to (001).

Superimposition of $02 l$ or $20 l$ (or their pseudohexagonal equivalents) reflection rows in SAED patterns and parallelism of lattice fringes of phyllosilicate intergrowths in altered biotite grains is common (e.g. Fig. 5), implying that the detrital biotite has been epitaxially replaced by chlorite, corrensite or $\mathrm{C} / \mathrm{S}$, i.e. the replacing layers retain the structural orientation of the biotite. Observations of streaks along $c^{*}$ in either $02 l$ or $20 l$ reflection rows and a lack of simultaneous occurrences of those reflection rows in such SAED patterns suggest the presence of disordered but non-turbostratic stacking sequences, consistent with the inferred epitaxial relations. 


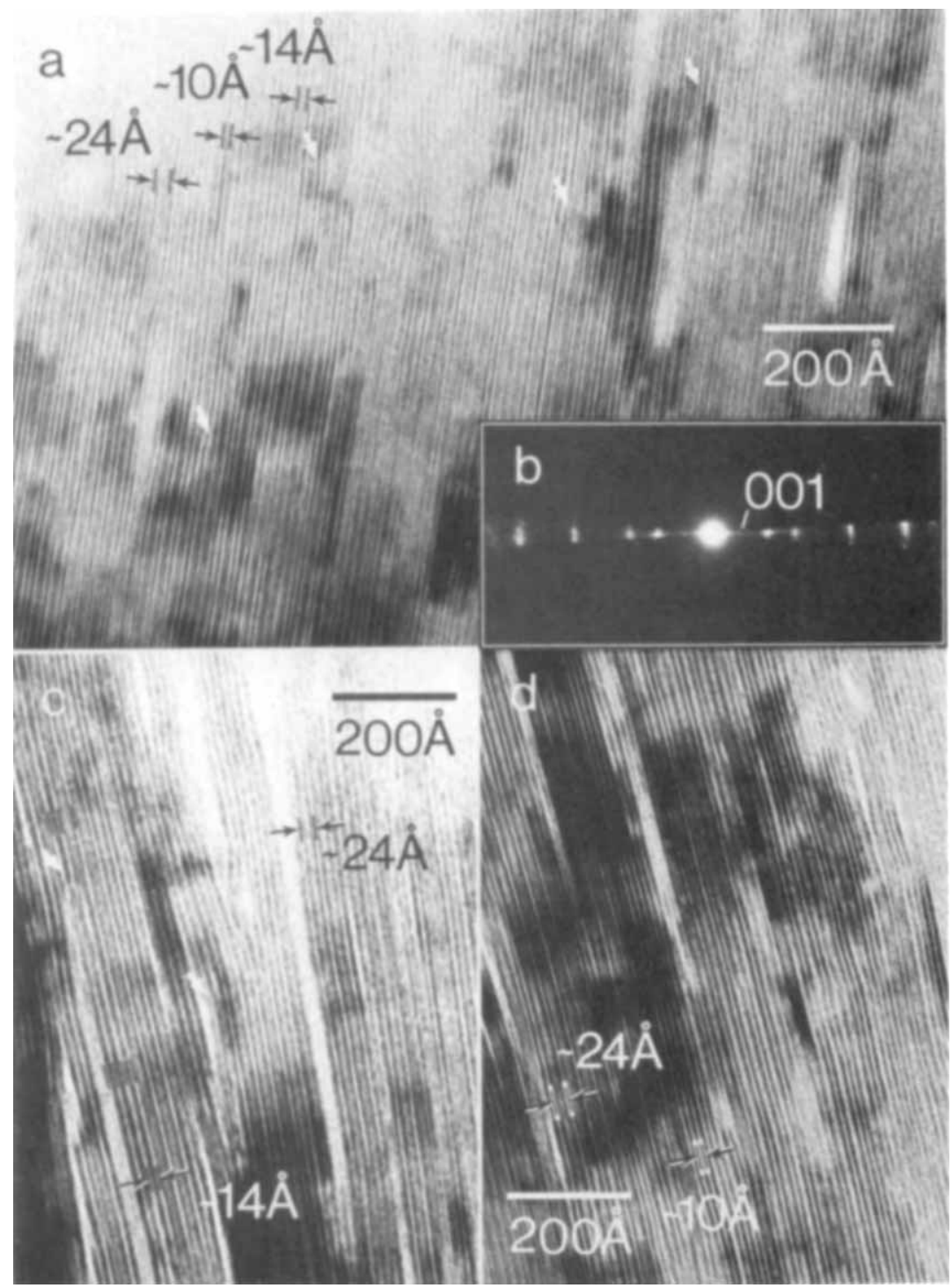

Fig. 4. (a) Lattice-fringe image of part of a flake in a corrensite-rich aggregate in sample A416. Terminations of smectite c. $10-\AA$ layers by chlorite c. $14-\AA$ layers are highlighted by white arrows. (b) Electron diffraction pattern of the corrensitedominated flake exhibits diffuse $00 l$ reflections of a $c$. $24-\AA$ phase that are accompanied by streaking along $c^{*}$. Latticefringe images of part of another flake showing (c) distortion of corrensite layers and (d) interstratification of corrensite with a relatively large number of excess, wavy layers of smectite.
Large areas of biotite layers are retained in some partially altered biotite grains (Fig. 6). A wide variety of layer terminations and mixed layers occur in such grains. Many terminations of one or two layers of biotite by a layer of chlorite occur (Fig. 6a). Some of such layer terminations occur in opposite directions in adjacent layers, as consistent with local strain caused by volume change occurring during the reactions (Banfield \& Eggleton, 1985). These types of layer terminations are irregularly distributed, giving rise to disordered interstratification of $c .10-\AA$ and $c .14-\AA$ layers. Such areas have no or very little $\mathrm{Ca}$ and $\mathrm{Na}$, and $\mathrm{K}$ and $\mathrm{Ti}$ contents are diminished, implying that little smectite accompanies the chlorite. By contrast, there are areas that contain some $\mathrm{Ca}$ and $\mathrm{Na}$ and reduced $\mathrm{Ti}$ and $\mathrm{K}$ contents and show wavy fringes resembling typical smectite layers (e.g. the middle of Fig. 6a). Such smectite-like materials are commonly associated with regions lacking lattice fringes. The latter may be a non-crystalline alteration product or, more likely, is beam-damaged smectite. Alternating $c$. 14- and c. 10- $\AA$ layers occur in some altered biotite grains (e.g. the upper right of Fig. 6a) and they are most likely corrensite because AEM analysis includes $\mathrm{Ca}$ and $\mathrm{Na}$ but shows low $\mathrm{K}$ and $\mathrm{Ti}$ contents relative to unaltered biotite, and because thick packets of corrensite commonly occur nearby. On the left of the smectite packet at the centre of Fig. 6(a), there is a termination of a chlorite layer plus a biotite layer by a chlorite layer, implying that the adjacent c. $10-\AA$ and c. $14-\AA$ layers are structurally related as in corrensite. The biotite-to-corrensite transition illustrated in Fig. 5(c) suggests the same structural relation.

Under optimal conditions, wavy smectite-like layers that have $10-12-\AA$ spacing and distinct contrast may be differentiated from biotite layers (Fig. 6b). Some of such fringes merge into biotite layers. Conversion of one biotite layer to one chlorite layer commonly occurs directly next to this type of fringe, resulting in corrensite-type fringes at one end (lower middle of Fig. 6b). In highly altered biotite 
Table 2. Selected and average analytical electron microscopy analyses of corrensite and detrital biotite in sample A416 of the diagenetic zone from Gaspé Peninsula. ${ }^{*} \dagger$

\begin{tabular}{|c|c|c|c|c|c|c|}
\hline & \multicolumn{2}{|c|}{ Corrensite } & \multicolumn{4}{|c|}{ Biotite } \\
\hline & 1 & 2 & 3 & 4 & 5 & 6 \\
\hline $\mathrm{Si}$ & 11.52 & 11.76 & 5.35 & 5.62 & 5.61 & 5.53 \\
\hline Al & 7.60 & 7.40 & 3.41 & 3.08 & 3.14 & 3.21 \\
\hline $\mathrm{Mg}$ & 8.42 & 8.98 & 2.14 & 1.72 & 1.66 & 1.84 \\
\hline $\mathrm{Fe}$ & 6.34 & 5.52 & 2.68 & 2.81 & 2.79 & 2.76 \\
\hline $\mathrm{Mn}$ & 0.14 & 0.14 & 0.06 & 0.06 & 0.06 & 0.06 \\
\hline $\mathrm{Ti}$ & 0 & 0 & 0.23 & 0.35 & 0.38 & 0.32 \\
\hline $\mathbf{K}$ & 0.44 & 0.56 & 1.69 & 1.66 & 1.60 & 1.65 \\
\hline $\mathrm{Na}$ & 0.34 & 0.28 & 0 & 0 & 0 & 0 \\
\hline $\mathrm{Ca}$ & 0.25 & 0.30 & 0 & 0 & 0 & 0 \\
\hline $\mathrm{Fe} / \mathrm{Mg}+\mathrm{Fe})$ & 0.43 & 0.38 & 0.56 & 0.62 & 0.63 & 0.60 \\
\hline $\mathbf{A l} /(\mathbf{S i}+\mathbf{A l})$ & 0.40 & 0.39 & 0.39 & 0.35 & 0.36 & 0.37 \\
\hline $\mathrm{SiO}_{2}$ & 31.92 & 33.02 & 35.58 & 37.38 & 37.39 & 36.80 \\
\hline $\mathrm{Al}_{2} \mathrm{O}_{3}$ & 17.87 & 17.63 & 19.24 & 17.38 & 17.76 & 18.12 \\
\hline $\mathrm{MgO}$ & 15.65 & 16.92 & 9.55 & 7.67 & 7.42 & 8.21 \\
\hline $\mathrm{FeO}$ & 21.01 & 18.54 & 21.31 & 22.35 & 22.23 & 21.96 \\
\hline $\mathrm{MnO}$ & 0.46 & 0.46 & 0.47 & 0.47 & 0.47 & 0.47 \\
\hline $\mathrm{TiO}_{2}$ & 0 & 0 & 2.03 & 3.10 & 3.37 & 2.83 \\
\hline $\mathrm{K}_{2} \mathrm{O}$ & 0.96 & 1.23 & 8.81 & 8.65 & 8.36 & 8.61 \\
\hline $\mathrm{Na}_{2} \mathrm{O}$ & 0.49 & 0.41 & 0 & 0 & 0 & 0 \\
\hline $\mathrm{CaO}$ & 0.65 & 0.79 & 0 & 0 & 0 & 0 \\
\hline
\end{tabular}

*Normalization is based on $40 \mathrm{O}+20 \mathrm{OH}$ and $20 \mathrm{O}+4 \mathrm{OH}$ for corrensite and biotite, respectively, and all $\mathrm{Fe}$ is assumed to be ferrous. $1=$ average of 10 analyses of matrix corrensite by Jiang \& Peacor (1994); 2 = selected analysis of corrensite in large phyllosilicate aggregates; $3-5$ and 6 selected and average analyses of biotite, respectively. Oxide weight percents are determined by calculation assuming totals of 89 and $97 \mathrm{wt} \%$ for corrensite and biotite. + Two standard deviations on the basis of counting statistics are $0.15-0.18$ and $0.11-0.13$ pfu (per formula unit) for Si, $0.13-0.15$ and $0.08-0.10 \mathrm{pfu}$ for $\mathrm{Al}, 0.14-0.16$ and $0.07-0.08 \mathrm{pfu}$ for $\mathrm{Mg}, 0.07-0.08$ and 0.06-0.07 pfu for $\mathrm{Fe}, 0.03-0.04$ and $0.06-0.07$ pfu for $\mathrm{K}$ in corrensite and biotite, respectively, and $\leq 0.03 \mathrm{pfu}$ for $\mathrm{Na}$ and $\mathrm{Ti}$, and $\leq 0.02 \mathrm{pfu}$ for $\mathrm{Ca}$ and $\mathrm{Mn}$ for all analyses.

grains, interstratified packets of corrensite and chlorite are dominant, with minor relict biotite or smectite layers (e.g. Fig. 7). Titanite is commonly present in the vicinity of such grains intergrown with the chloritic minerals, the $\mathrm{Ti}$ presumably having its source in biotite. In addition to the coarse-grained biotite shown above, there are some relatively straight, thin packets of Ti-bearing, $10-\AA / 14-\AA$ mixed layers in the matrix (not shown), most likely being the alteration product of finer grained biotite.

\section{PROGRADE MODIFICATION OF PHYLLOSILICATE STACKS}

Instead of detrital biotite, coarse-grained phyllosilicate stacks occur in the higher grade rocks, consisting principally of chlorite and muscovite and surrounded by fine-grained matrix minerals. The size of such phyllosilicate stacks varies from grain to grain but the average size appears to increase with increasing grade. The proportion of chlorite relative to muscovite in the phyllosilicate stacks is variable but chlorite generally occupies a larger volume than does muscovite.

\section{Samples from the anchizone}

In addition to the chlorite-muscovite stacks, there are two other types of phyllosilicate intergrowths in sample R299 of the lower anchizone (distinguished from sample 89-12 by its illite crystallinity index). The first contains some remnants of detrital biotite and aggregates of chlorite ( \pm illite) and $\mathrm{C} / \mathrm{S}$ constituting phyllosilicate stacks (Fig. 8a) and the second consists of aggregates of chlorite, illite and corrensite or $\mathrm{C} / \mathrm{S}$ without remnants of biotite (Fig. $8 \mathrm{~b}$ ) in a matrix of quartz, albite, calcite and fine-grained clay minerals. Titanite is commonly associated with those mineral intergrowths. Both titanite and anatase (identified by EDS and TEM) occur in the matrix and the chlorite-muscovite stacks of sample R299, but only anatase was observed in sample 89-12 of the high anchizone (Fig. 9a). Euhedral crystals of anatase occur together with calcite and quartz in the matrix of sample 89-12 (Fig. 9b).

Textures of chlorite-muscovite stacks are illustrated in Fig. 9(c). There are two chlorite-muscovite stacks that contain very different proportions of chlorite and muscovite, the larger one being dominated by chlorite and having elongated pyrite inclusions and some muscovite in fissures produced by separation along (001). The phyllosilicate stacks in the anchizonal rocks typically have their long aspects and (001) parallel or subparallel to bedding and rock cleavage and exhibit local or pervasive deformation (Figs $8 \& 9$ ). There is no clear evidence for pressure solution.

A lattice-fringe image of part of a chlorite-illitecorrensite aggregate in sample R299 is shown in Fig. 10. The chlorite and corrensite (or smectite) layers display complex mixed layering and layer terminations, associated with the formation of illite. X-ray maps of $\mathrm{Mg}$ and $\mathrm{Fe}$ from part of a chlorite-muscovite stack in sample R299 show that relatively $\mathrm{Mg}$-rich chlorite is directly adjacent to relatively $\mathrm{Fe}$-rich chlorite, with a well-defined boundary (Fig. 11), whereas areas with weak $\mathrm{Fe}$ and $\mathrm{Mg} \mathrm{X}$-ray signals are muscovite. The relatively Fe-rich chlorite packets on the left display strong X-ray signals of both $\mathrm{Mg}$ and $\mathrm{Fe}$ because of greater specimen thickness. Muscovite in phyllosilicate stacks is invariably a two-layer polytype (e.g. Fig. 12a) and has a higher interlayer charge and $\mathrm{Fe} /(\mathrm{Mg}+\mathrm{Fe})$ ratio than white mica in the matrix.

TEM images of part of the phyllosilicate stack in Fig. 11 show that the relatively $\mathrm{Mg}$-rich chlorite packets at the edges of the chlorite-muscovite stack are deformed, with crystal kinking and buckling occurring in the cleavage plane as indicated by the contrast bands normal or subnormal to (001) (Fig. 12). No obvious deformation features were observed in the muscovite and relatively Fe-rich chlorite. The compositions of both types of chlorite (Table 3) fall in the compositional range of the matrix chlorite (Jiang \& Peacor, 1994). Nevertheless, the texture clearly suggests an overgrowth relation between two types of chlorite. Similar compositional relations between the phases in the large phyllosilicate stacks and those in the matrix were also observed in sample 89-12 of the 


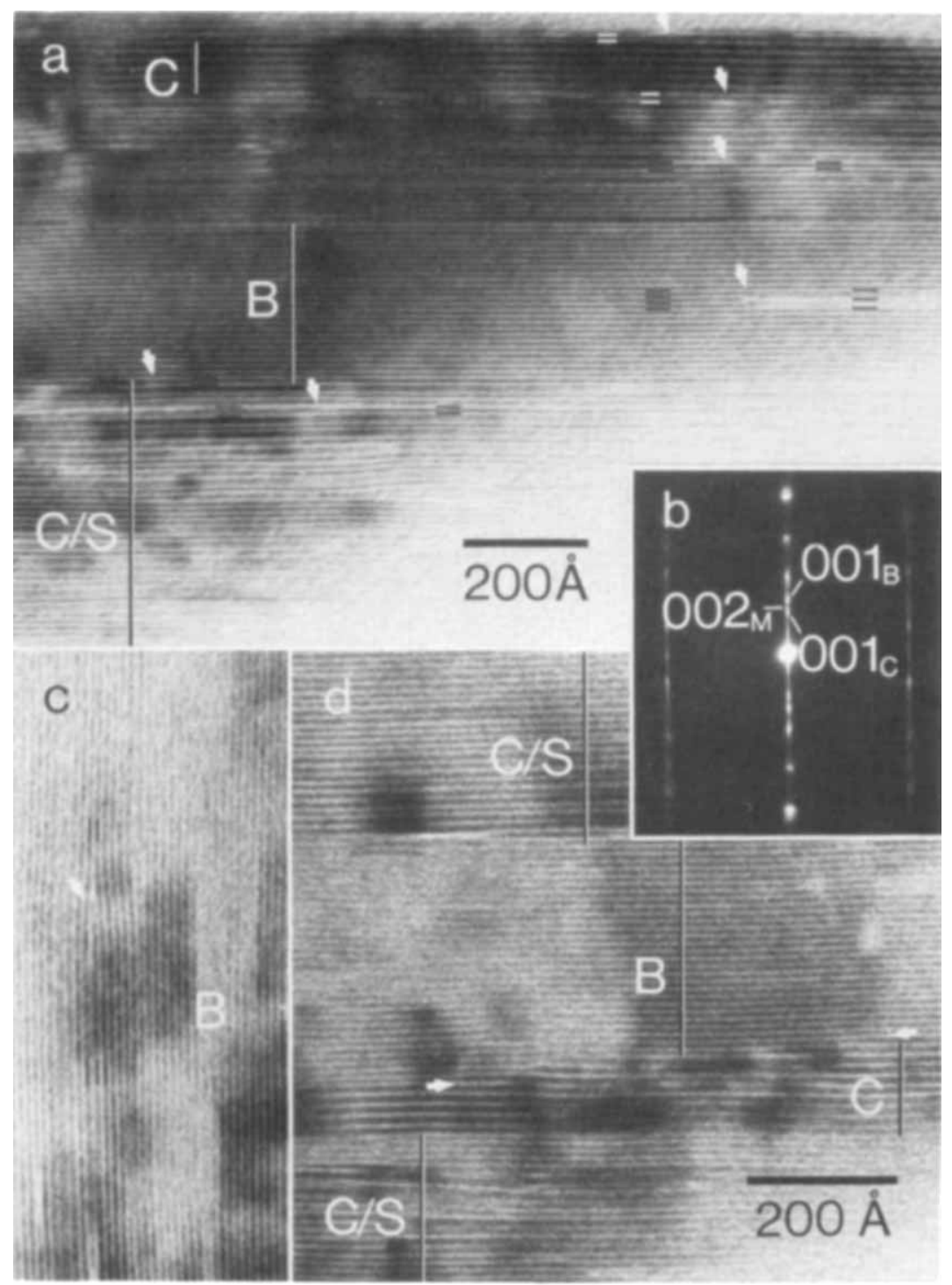

Fig. 5. (a) Lattice-fringe image of a partially altered biotite packet in sample A416. Terminations of layers are highlighted with white arrows. (b) Electron diffraction pattern of an area including (a). The 001 reflections of biotite and chlorite correspond to $d$-values of $c .10$ and $c .14 \AA$, respectively. The reflection labelled $00 I_{M}$ has a $d$-value of $c .12 \AA$, and is associated with intense streaking along $c^{*}$. (c) and (d) show a termination of a biotite layer by a corrensite-like $c$. 24- $\AA$ layer and

terminations of consecutive biotite layers against multiple chlorite layers in other biotite grains, respectively. B, biotite; C, chlorite; $\mathrm{C} / \mathrm{S}$, mixed-layer chlorite/smectite. high-grade anchizone (Tables $1 \& 3$ ), but no corrensite occurs.

\section{Sample from the epizone}

The long aspects and (001) of phyllosilicate stacks in the epizonal rock are parallel or subparallel to bedding but normal or subnormal to a spaced cleavage. The phyllosilicate stacks commonly show relatively strong deformation features compared with those in lower grade rocks. A chlorite-muscovite intergrowth consisting of a thick and several thin lamellae of muscovite typical for sample R245 of the epizone is shown in Fig. 13(a). Several of the thin muscovite lamellae appear to be disassociated from the thick muscovite lamella and separated by chlorite units of variable thicknesses. A separate muscovite lamella at the top of the phyllosilicate stack does not display any deformation features and has an EDS spectrum similar to that obtained for matrix muscovite (relatively Mg-rich) but different from that obtained for the thick lamella (relatively $\mathrm{Fe}$-rich). A matrix muscovite grain that formed parallel to the rock cleavage occurs at the edges of the stack in the upper left. In the middle left, a muscovite grain that appears to be a part of the phyllosilicate stack but has a composition similar to that of the matrix muscovite has an irregular boundary in contact with the adjacent chlorite. The chlorite-muscovite stack also has crooked boundaries with the surrounding quartz, part of which is enclosed within the stack. Rutile and pyrite and pyrrhotite that are partially replaced by magnetite occur in the matrix as well as in the phyllosilicate stack.

Truncations of chlorite-muscovite stacks by the spaced cleavage and local growth of the constituting chlorite and muscovite in a direction parallel to the cleavage are common in the epizonal rock (Fig. 13b). Such a feature may be caused by pressure solution and recrystallization. Thin muscovite lamellae that taper from the edges into the interior of chlorite-muscovite stacks occur commonly, 
Fig. 6. Lattice-fringe images of an altered biotite grain (sample A416) showing (a) smectite-like wavy layers in the middle, corrensite-like $c$. 24-Â units in the upperright and various types of layer transitions (highlighted with white arrows), and (b) $10-12-\AA$ layers with distinct contrast terminated against (marked by white arrows) and interstratified with biotite layers. Association of such layers with terminations of $c$. 10 - $\AA$ layers by $14-\AA \AA$ layers, forming corrensite-like units, are highlighted with fine black bars.

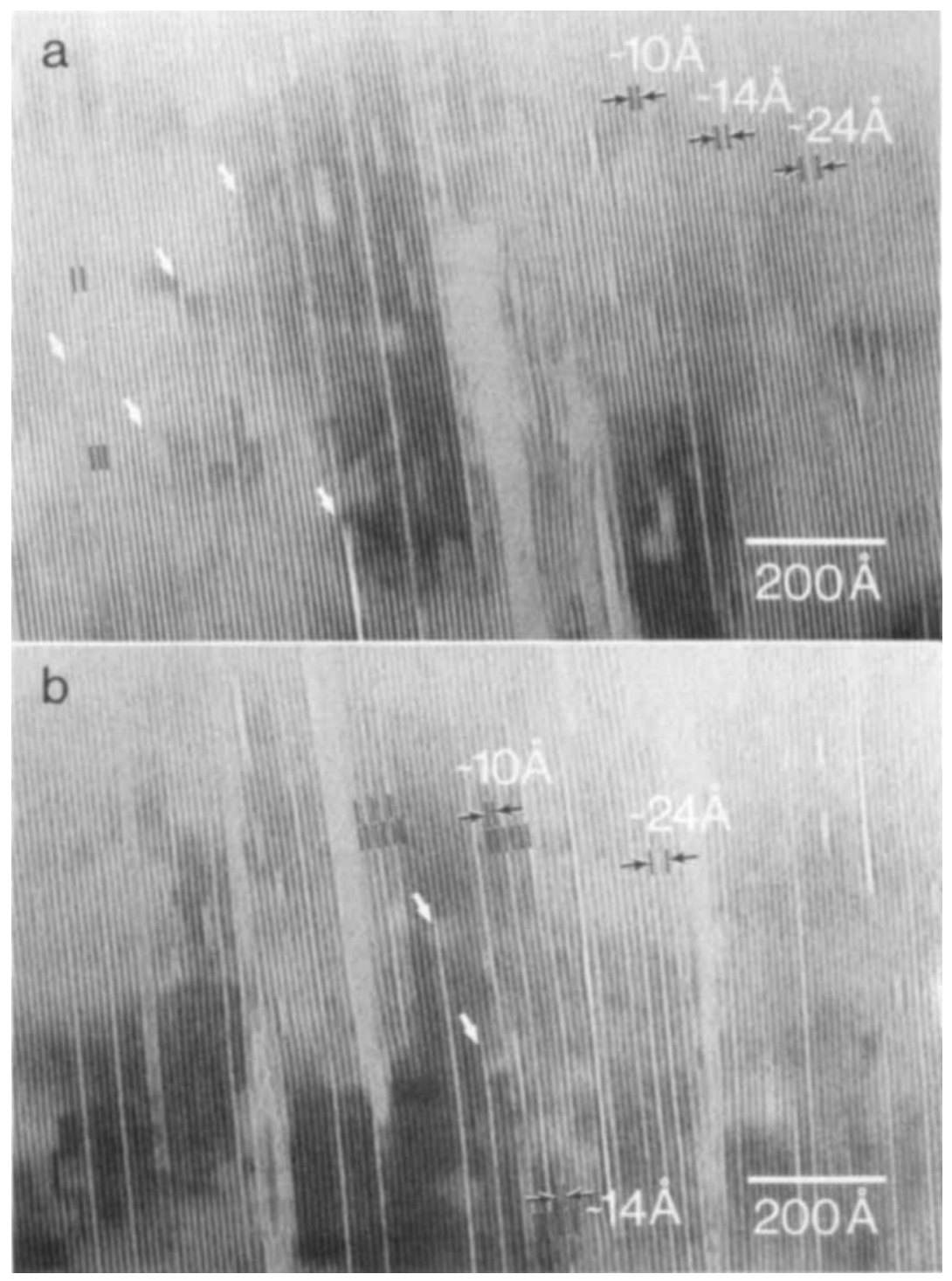

implying infilling by muscovite or a precursor phase in fissures produced by separation along (001).

The composition of chlorite in sample R245 of the epizone is rather uniform regardless of the textures and structures (Table 3; also see Jiang \& Peacor, 1994). The composition of muscovite falls into two different groups; relatively $\mathrm{Fe}$-rich muscovite is restricted largely to large chlorite-muscovite stacks and relatively $\mathrm{Mg}$-rich muscovite occurs primarily in the matrix (Table 1). Figure 14(a) shows an intergrowth of muscovite crystals that have compositions characteristic of the relatively $\mathrm{Mg}$-rich matrix muscovite and the relatively Fe-rich stack muscovite (Table 1), respectively, in a chlorite-muscovite stack in sample R245. The relatively Fe-rich and $\mathrm{Mg}$-rich muscovite packets on the left have a well-defined boundary parallel to their common (001) plane. Part of the relatively Mg-rich muscovite is curved toward a relatively straight packet that has an angular boundary with another packet.

In some of the chlorite-muscovite stacks, strain features occur irregularly throughout individual crystals like those shown in Fig. 14(b). There the strained chlorite area contains many stacking faults as linear features with distinct contrast parallel to (001), and has kinked zones giving contrast bonds subnormal to the cleavage plane. The area beneath appears to be free of strain and bordered by a subgrain boundary consisting of clusters of dislocations (white arrow).

\section{DISCUSSION}

\section{Formation of corrensite through alteration of detrital biotite during diagenesis}

The relations observed for the prograde sequence demonstrate a process of replacement of detrital biotite by complex, heterogeneous sequences of corrensite and chlorite layers, with subsequent replacement of those trioctahedral phases by homogeneous chlorite. The origin 


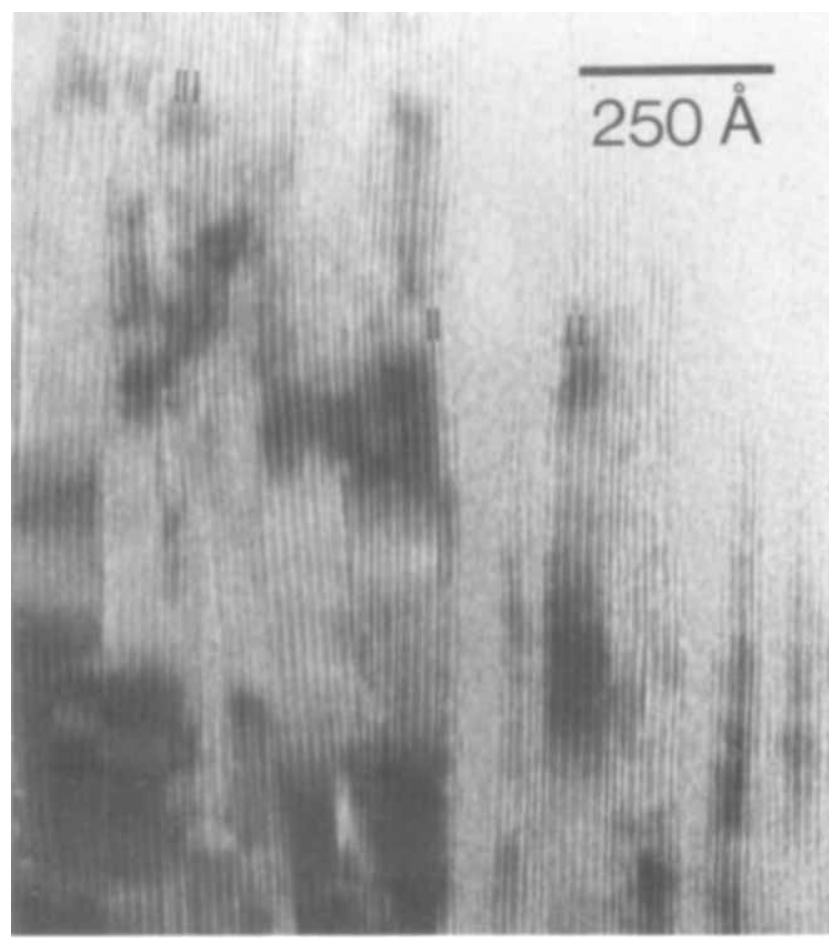

Fig. 7. Lattice-fringe image of packets of chlorite (wide fringes, right) and corrensite (wide + narrow fringes, left) interstratified with minor smectite layers (narrow fringes) in a highly altered biotite grain (sample A416).

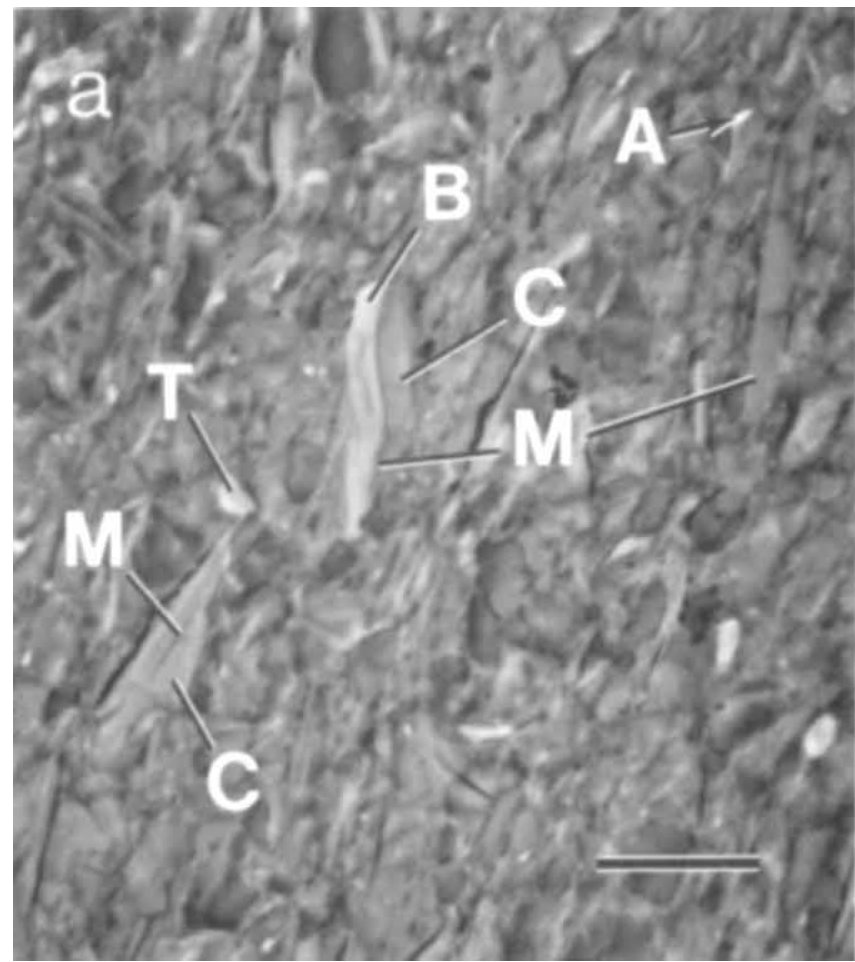

of the complex chlorite and corrensite layer sequences is indicated by: (1) the presence of abundant biotite in the lower grade rock, occurring as aggregates of sedimented grains having angular shapes typical of detrital grains. The Ti content and overall composition suggest that the biotite was of volcanic origin. Biotite occurs only sparingly in the lower-grade anchizonal sample and then has the appearance of a relict phase. There is no biotite in higher grade samples, as consistent with progressive alteration of original, detrital material. (2) Complex sequences of chlorite and corrensite layers were observed to replace layers of detrital biotite in the sample of diagenetic grade. Along-layer transitions of biotite to chlorite or corrensite are abundant. (3) Although biotite occurs only rarely in the low-grade anchizonal sample, grains consisting of complex sequences of corrensite and chlorite layers are abundant. That is, as the proportion of biotite decreases with increasing grade, the proportion of corrensite and chlorite increases. (4) Intimate intergrowths of titanite with corrensite-rich material were ubiquitously observed in the lower grade rocks (the titanite is replaced by rutile or anatase in higher grade rocks), but the only $\mathrm{Ti}$ detected in association with biotite occurred in solid solution. This implies that alteration of biotite gave rise to the $\mathrm{Ti}$ essential to titanite, with Ti-free corrensite and chlorite replacing the biotite. Titanite and anatase or rutile have been observed elsewhere to be common alteration products of Ti-bearing biotite (e.g. Eggleton \& Banfield, 1985; Claeys \& Mount, 1991).

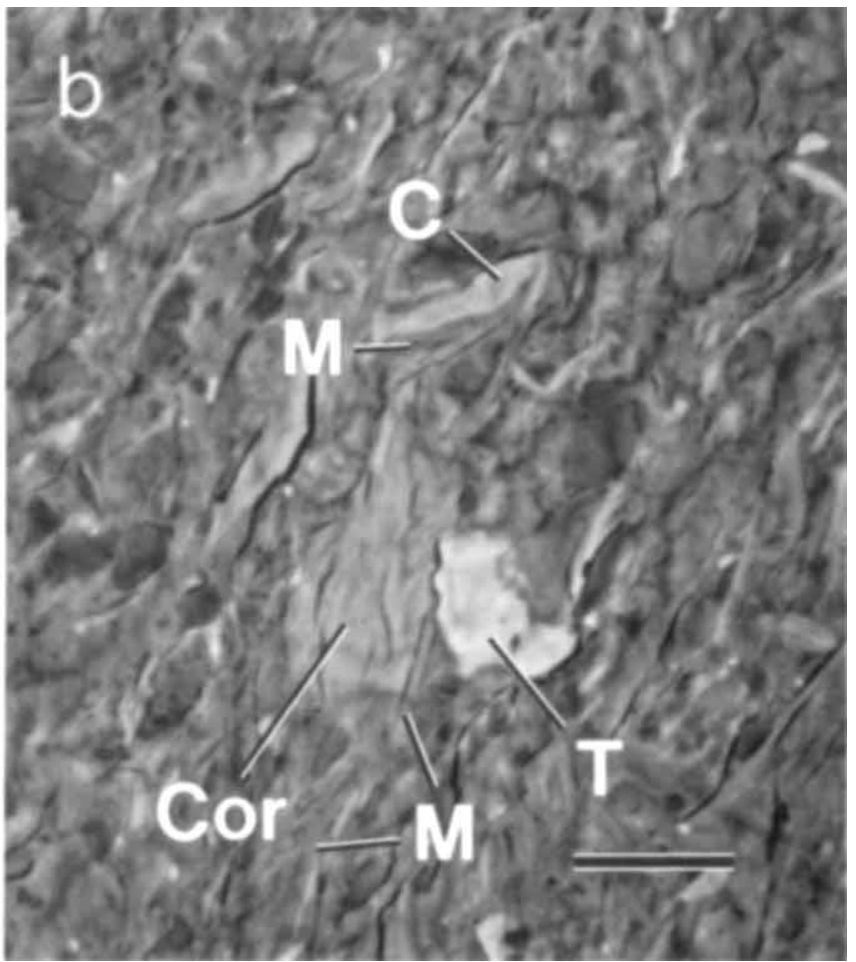

Fig. 8. Back-scattered electron images of the anchizonal sample R299 showing (a) remnant biotite (B) intergrown with chlorite (C) and phengitic muscovite (M), and (b) an aggregate of chlorite, corrensite (Cor) and illitic mica (M), associated with a titanite grain (T), in a matrix of quartz, albite, titanite and very fine-grained clay minerals. Irregular grains with dark grey contrast are quartz or albite. A, anatase. Scale bars $=10 \mu \mathrm{m}$. 

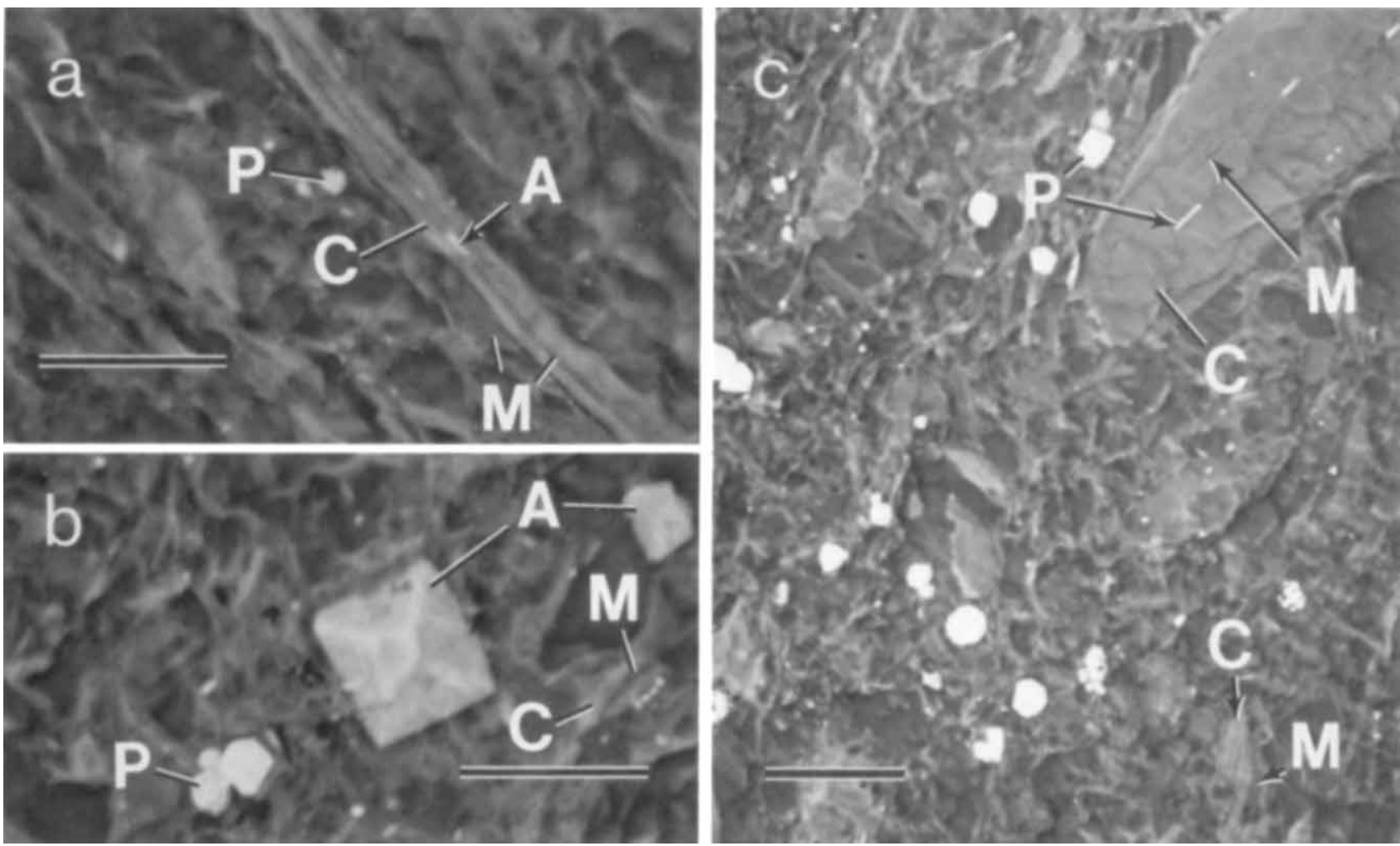

Fig. 9. Back-scattered electron images of anchizonal sample 89-12 showing (a) an anatase inclusion in a chlorite-muscovite stack, (b) a euhedral anatase grain surrounded by matrix minerals and (c) two chlorite-muscovite stacks with different proportions of chlorite (C) relative to muscovite $(\mathrm{M})$. Dark grey grains are quartz or albite and elongated, medium grey grains in the matrix are chlorite and illite. A, anatase; $\mathrm{P}$, pyrite or pyrrhotite. Scale bars $=10 \mu \mathrm{m}$.

The presence of delicate interlocking and deformation textures, the close association of corrensite and partially altered biotite with titanite and magnetite, and the albitization of feldspars and formation of framboidal magnetite indicate that pervasive diagenetic processes have occurred even in the lowest grade samples, as consistent with the corrensite being of late diagenetic origin (Jiang \&
Peacor, 1994). The textures, including the presence of a number of hybrid layers in slightly altered biotite, interstratification of packets of biotite with thin packets of chlorite and corrensite, interstratification of corrensite and chlorite with minor relict biotite layers, intergrowths of altered biotite with corrensite-rich aggregates, and aggregates of randomly orientated, corrensite-dominant
Fig. 10. Lattice-fringe image of interstratified packets of chlorite (C), illite (I) and mixed-layer chlorite/smectite (C/S) (or chlorite/corrensite) from sample R299. Terminations of smectite layers by chlorite layers are marked by white arrows.

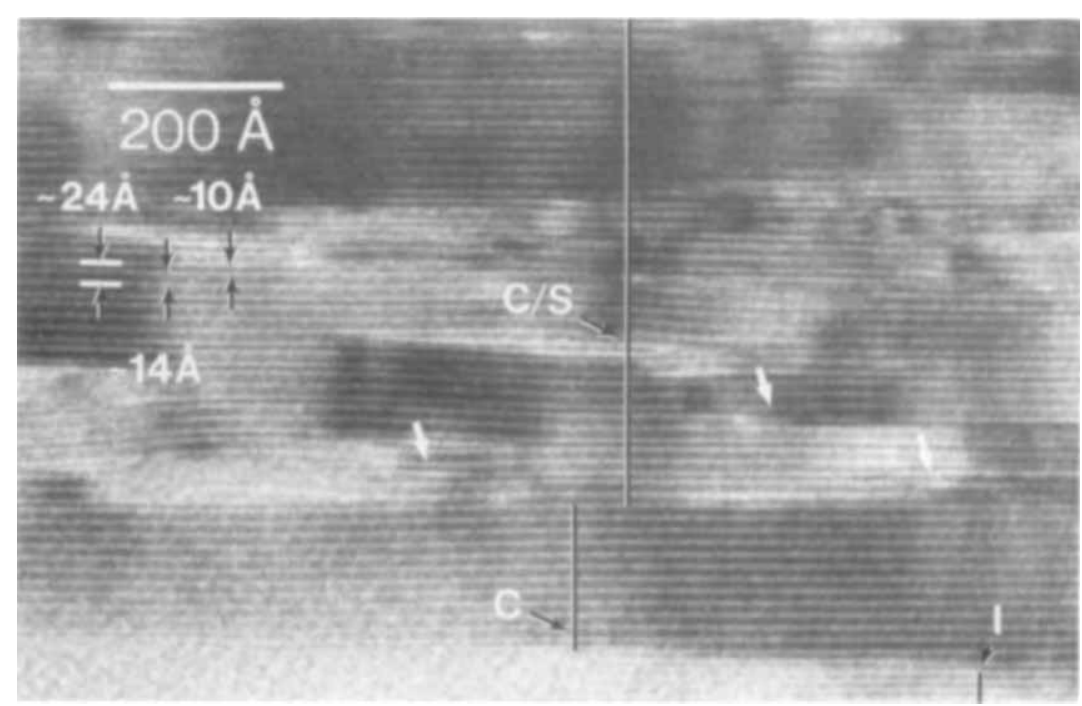




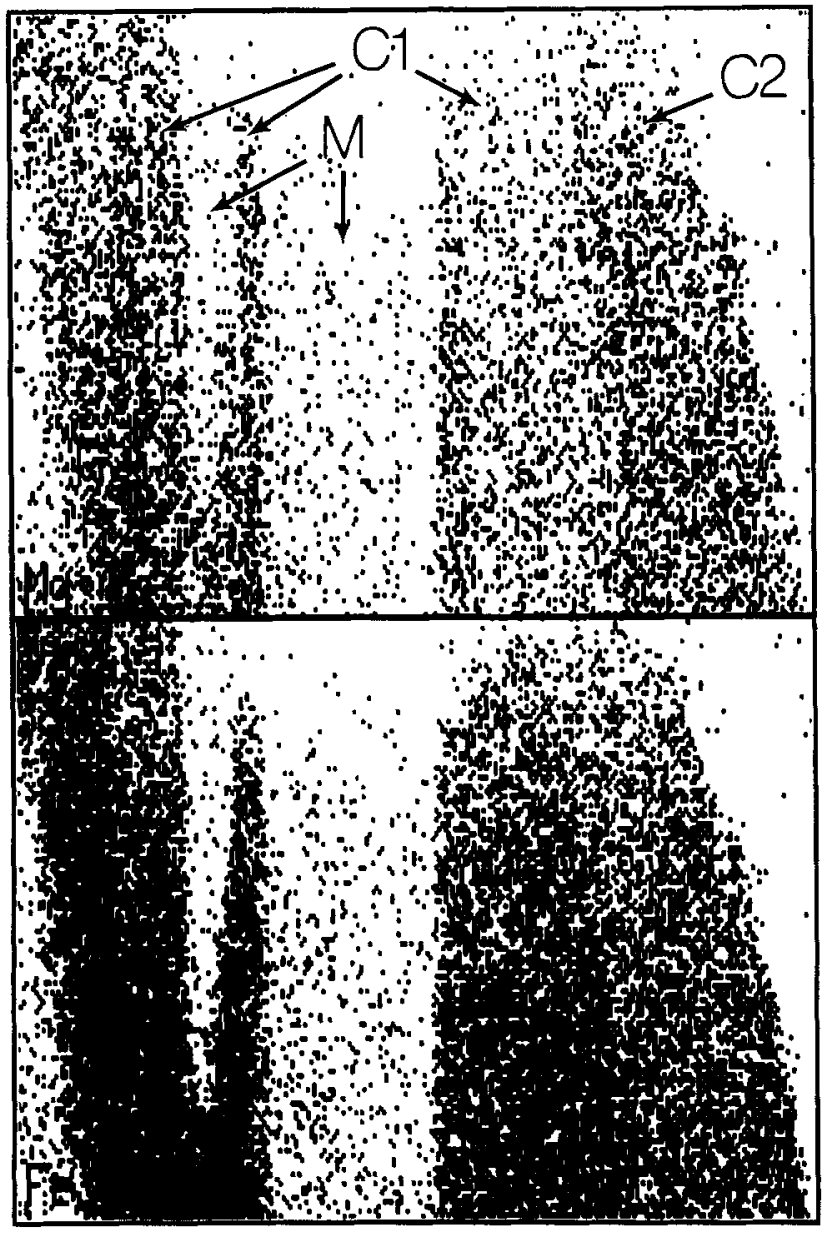

Fig. 11. X-ray maps of $\mathrm{Mg}$ (above) and Fe (below) obtained at the edges of a chlorite-muscovite stack in sample R299.

Relatively $\mathrm{Mg}$-rich chlorite (C2) is directly adjacent to relatively Fe-rich chlorite (Cl) with a well-defined boundary. Muscovite (M) has only small $\mathrm{Mg}$ and Fe concentrations.

flakes, therefore represent different sages of alteration or different alteration mechanisms occurring as part of the diagenetic processes.

The data collectively demonstrate that most of the corrensite in the Gaspé rocks was formed from the diagnetic alteration of detrital biotite. Other detrital minerals or volcanic glass may have been a source for some of the fine-grained matrix phyllosilicates. The presence of relatively abundant $\mathrm{I} / \mathrm{S}$ in the matrix of the lowest grade sample A419 (Jiang \& Peacor, 1994) implies the prior occurrence of dioctahedral smectite, with trioctahedral phyllosilicates in the matrix possibly being in part derived from the trioctahedral component of such smectite upon formation of $\mathrm{I} / \mathrm{S}$, resembling those occurring in the Gulf Coast sediments (Boles \& Franks, 1979). Unfortunately rocks of early diagenetic grade are not available for the observations of such relations. Reactions between dolomite and dioctahedral clays may similarly produce trioctahedral clays (Hillier, 1993). We observed no evidence of such relations, however.

\section{Alteration mechanisms}

The alteration of biotite to chloritic minerals is inferred to occur through two mechanisms: (1) replacement of individual or multiple layers, and (2) dissolutiontransport-precipitation.

\section{Replacement of individual or multiple layers}

This mechanism is evidenced by the presence of interstratified packets of biotite and chloritic minerals of variable thicknesses, and by terminations of biotite layers by layers of chlorite, corrensite and smectite. There are four modes of transition involved in these relations, including conversion of: (1) one biotite layer to one chlorite layer, smectite, or corrensite, (2) two biotite layers to one chlorite layer, (3) three biotite layers to two chlorite layers, (4) multiple biotite layers to multiple layers of chlorite, corrensite, or smectite.

Only the first and fourth types of conversion will be discussed here because they are the primary replacement mechanisms. The former also occurs in alteration of trioctahedral micas to chlorite elsewhere, with replacement of the $\mathrm{K}$ interlayer of mica by the brucite-like sheet of chlorite (e.g. Olives \& Amouric, 1984; Yau et al., 1984; Eggleton \& Banfield, 1985). In the Gaspé rocks, this type of layer transition is locally accompanied by smectitization of adjacent biotite laers to form corrensite, i.e. two biotite layers are transformed to a corrensite unit. Such a process involves minimal structural adjustments as compared with other types of layer transitions. Both chlorite or smectite layers were observed in the process of replacing single biotite layers and the ultimate result is formation of corrensite plus chlorite, although some of the chlorite may have formed by diagenesis of corrensite and other phases as suggested by Jiang \& Peacor (1994).

Replacement of several successive layers with interfaces or alteration fronts orientated perpendicular or oblique to (001) has only been rarely observed in a few studies of phyllosilicate alteration (e.g. Yau et al., 1984; Jiang et al., 1992; Jiang \& Peacor, 1993). The alteration fronts observed in those studies involved very little volume change at interfaces but, in this study, such replacements were associated with a large volume increase. Stress resulting from such a volume increase is accommodated by the presence of layer replacements in the opposite direction in nearby regions and by the volume decrease occurring as the result of conversion of two layers of biotite to one layer of chlorite. However, such accommodation of stress occurs only locally during alteration. Where such replacement of several layers of biotite by chloritic layers advances to completion in the absence of other alteration mechanisms, the large increase in volume would have to be compensated by adjustment of grain boundaries or by dissolution of some altering material.

No matter which type of layer replacement took place, preservation of entire biotite 2:1 layers is not possible. The changes in octahedral contents and layer charge and the 
Fig. 12. (a) TEM image of part of the chlorite-muscovite stack shown in Fig. 11. Kinking and bending of relatively $\mathrm{Mg}$-rich chlorite $(\mathrm{C} 2)$ are evidenced by the contrast band and the curvature of crystals.

Relatively Fe-rich chlorite $(\mathrm{Cl})$ and muscovite (M) do not have such features. Inset: an electron diffraction pattern obtained on the thin edges of the muscovite showing reflections of a two-layer polytype $[d(002)=c .10 \AA]$. (b) Lattice-fringe image of part of (a) showing crystal kinking within a relatively $\mathrm{Mg}$-rich chlorite crystal. The kinks terminated inside the crystal and are surrounded by relatively undeformed layers. Terminations of 001 layers occur at the boundary between two nearly parallel packets of layers in the lower left.
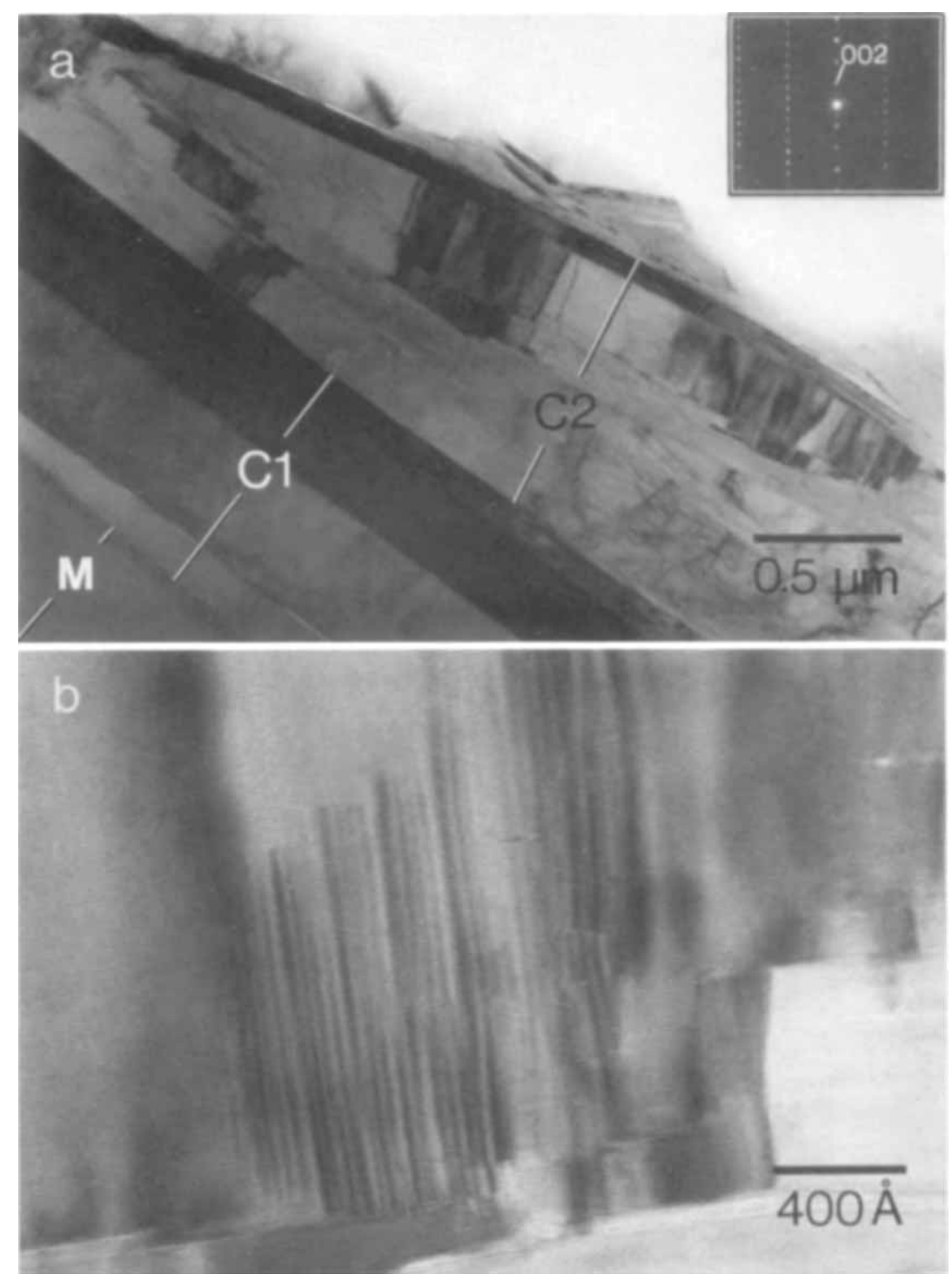

loss of $\mathrm{Ti}$ are significant, requiring destruction of original octahedral bonds and reconstruction and addition of individual sheets. The degree of involved chemical changes can be exemplified using the following equation for the biotite-to-corrensite reaction by assuming conservation of Al:

$$
\begin{aligned}
& 1 \text { biotite }+0.2 \mathrm{Na}^{+}+0.4 \mathrm{Ca}^{2+}+1.9 \mathrm{Mg}^{2+}+7.2 \mathrm{H}_{2} \mathrm{O} \\
& =0.4 \text { corrensite }+0.3 \text { titanite }+0.2 \mathrm{SiO}_{2}
\end{aligned}
$$$$
+0.02 \mathrm{Fe}^{2+}+1.5 \mathrm{~K}^{+}+3.1 \mathrm{H}^{+} \text {, }
$$

where

$$
\begin{aligned}
\text { biotite }= & \mathrm{K}_{1.7}\left[\mathrm{Fe}_{2.8} \mathrm{Mg}_{1.8} \mathrm{Al}_{0.8} \mathrm{Ti}_{0.3}\right]\left[\mathrm{Si}_{5.5} \mathrm{Al}_{2.5}\right] \mathrm{O}_{20}(\mathrm{OH})_{4}, \\
\text { corrensite }= & \mathrm{K}_{0.4} \mathrm{Na}_{0.4} \mathrm{Ca}_{0.2}\left[\mathrm{Fe}_{6.4} \mathrm{Mg}_{8.4} \mathrm{Al}_{3.2}\right] \\
& \times\left[\mathrm{Si}_{11.6} \mathrm{Al}_{4.4}\right]_{\mathrm{O}_{40}}(\mathrm{OH})_{20}
\end{aligned}
$$

and titanite $=\mathrm{CaTiSiO}_{5}$. All the coefficients are approximated to the one decimal place for simplicity. Such changes could proceed at sufficiently rapid rates only through dissolution and crystallization via a fluid medium rather than by solid-state diffusion at low temperatures. The process is similar to the layer-by-layer dissolution mechanism proposed by Altaner (1989) for smectite-toillite reactions. Mineral interfaces could well serve as the fluid conduit along which transport of reactants and products occurs.

\section{Dissolution-transport-precipitation mechanism}

This mechanism is suggested by the formation of aggregates of randomly orientated flakes of corrensite and fine-grained corrensite in the matrix, both of which have irregular interlocking textures with other phases. Formation of such corrensite requires a significant volume increase $(40-50 \%)$ if it occurs by a layer-by-layer replacement of biotite, as inconsistent with those textures. Some relict biotite grains are adjacent to corrensite-rich 
Table 3. Represcntative analytical electron microscope analyses of chlorite in pelitic rocks from the Gaspé Peninsula. ${ }^{*}+$

\begin{tabular}{|c|c|c|c|c|c|c|c|}
\hline \multirow[t]{2}{*}{ Sample } & \multirow{2}{*}{$\frac{A 416}{1}$} & \multicolumn{2}{|c|}{ R299 } & \multicolumn{2}{|c|}{$89-12$} & \multicolumn{2}{|c|}{ R245 } \\
\hline & & 2 & 3 & 4 & 5 & 6 & 7 \\
\hline Si & 5.27 & 5.34 & 5.58 & 5.32 & 5.41 & 5.48 & 5.42 \\
\hline Al & 5.45 & 5.32 & 4.89 & 5.25 & 5.17 & 5.09 & 5.14 \\
\hline $\mathrm{Mg}$ & 4.60 & 4.81 & 5.78 & 5.24 & 4.80 & 5.49 & 5.35 \\
\hline $\mathrm{Fe}$ & 4.57 & 4.44 & 3.75 & 4.11 & 4.49 & 3.90 & 4.04 \\
\hline Mn & 0.10 & 0.09 & 0 & 0.08 & 0.13 & 0.04 & 0.08 \\
\hline $\mathrm{Fe} /(\mathrm{Mg}+\mathrm{Fe})$ & 0.50 & 0.48 & 0.39 & 0.44 & 0.48 & 0.42 & 0.43 \\
\hline $\mathrm{Al} /(\mathrm{Si}+\mathrm{Al})$ & 0.51 & 0.50 & 0.47 & 0.50 & 0.49 & 0.48 & 0.49 \\
\hline $\mathrm{SiO}_{2}$ & 25.27 & 25.69 & 27.45 & 25.87 & 25.97 & 26.81 & 26.37 \\
\hline $\mathrm{Al}_{2} \mathrm{O}_{3}$ & 22.17 & 21.72 & 20.41 & 21.67 & 21.06 & 21.13 & 21.21 \\
\hline $\mathrm{MgO}$ & 14.80 & 15.53 & 19.08 & 17.10 & 15.46 & 18.02 & 17.46 \\
\hline $\mathrm{FeO}$ & 26.20 & 25.55 & 22.06 & 23.90 & 25.77 & 22.81 & 23.50 \\
\hline $\mathrm{MnO}$ & 0.57 & 0.51 & 0 & 0.46 & 0.74 & 0.23 & 0.46 \\
\hline
\end{tabular}

*Normalization is based on $20 \mathrm{O}+16 \mathrm{OH}$. All $\mathrm{Fe}$ is assumed to be ferrous. Alkalis $(<0.03)$, Ca $(<0.02)$ and $\mathrm{Ti}(<0.01)$ are present only in a few analyses and not listed. Oxide weight percents are determined by calculation assuming a total of $89 \mathrm{wt} \%$. †Two standard deviations on the basis of counting statistics are 0.14-0.17 per formula unit (pfu) for Si and $\mathrm{Al}, 0.12-0.18 \mathrm{pfu}$ for $\mathrm{Mg}, 0.07-0.12 \mathrm{pfu}$ for $\mathrm{Fe}$ and $0.01-0.03$ for $\mathrm{Mn}$. $\ddagger$ Analyses $1,3,5,7=$ chlorite in matrix (sclected from Jiang \& Peacor, 1994); $2,4,6=$ chlorite in chlorite-muscovite stacks.

aggregates with well-defined boundaries but do not have regular orientational relationships with clay flakes contained there and no pre-existing biotite layers are

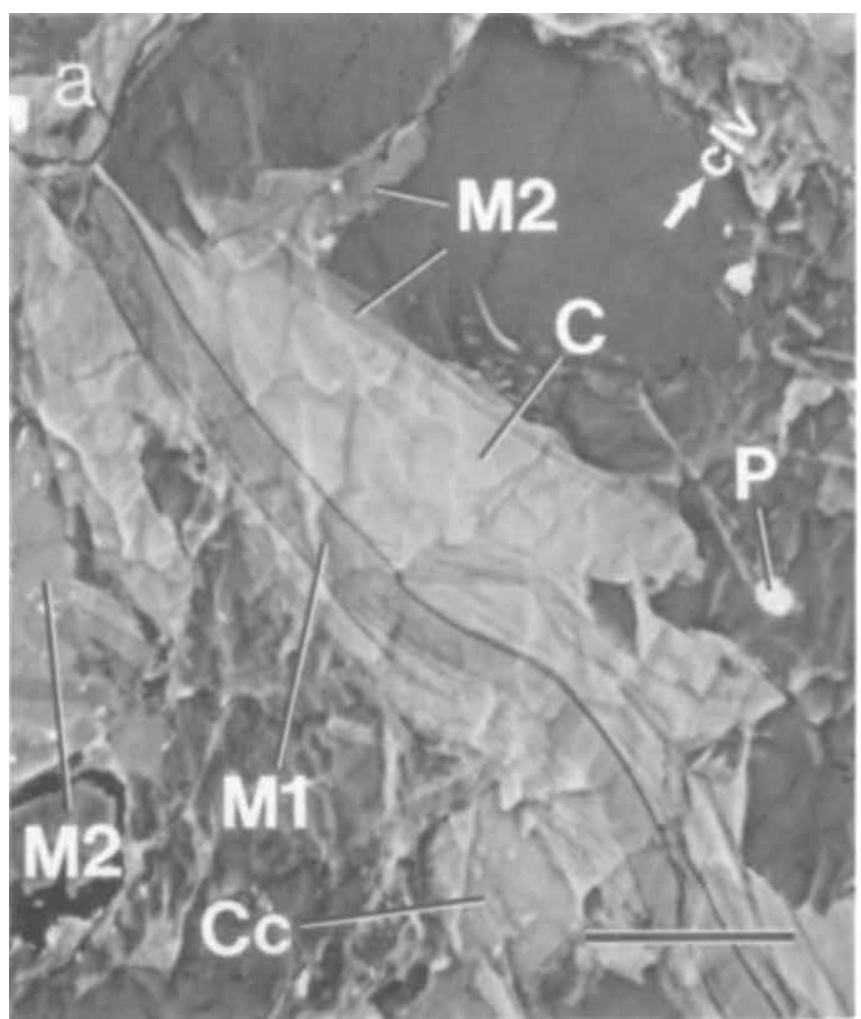

interstratified with this type of corrensite. The alteration is therefore inferred to have involved: (1) wholesale dissolution of some of the biotitite, its alteration products, or other detrital materials such as volcanic glass, (2) transport of dissolved materials through a fluid medium to precipitation sites and (3) direct precipitation of chloritic minerals in the matrix, filling space between other phases. However, the related chemical constituents may have been in part derived from alteration of other phases discussed above.

\section{Formation of phyllosilicate stacks}

Phyllosilicate stacks consist of alternating packets of trioctahedral and dioctahedral materials, having an overall angular shape typical of a detrital grain. The minerals comprising the stacks change from biotiote, to biotite + corrensite + chlorite $\pm 1 M_{\mathrm{d}}$ illite in the diagenetic rocks, through chlorite + muscovite \pm biotite \pm corrensite in the anchizone, to chlorite + muscovite in the epizone.

As a first step in that sequence, biotite was completely or partially altered to form chlorite + corrensite as described above. Because a source of $K$ is required for the formation and maturation of the white mica portions of the stacks, we infer that the $K$ produced as a product of progressive alteration of biotite (Eq. 1) and its expandable alteration products serves as a component of the white

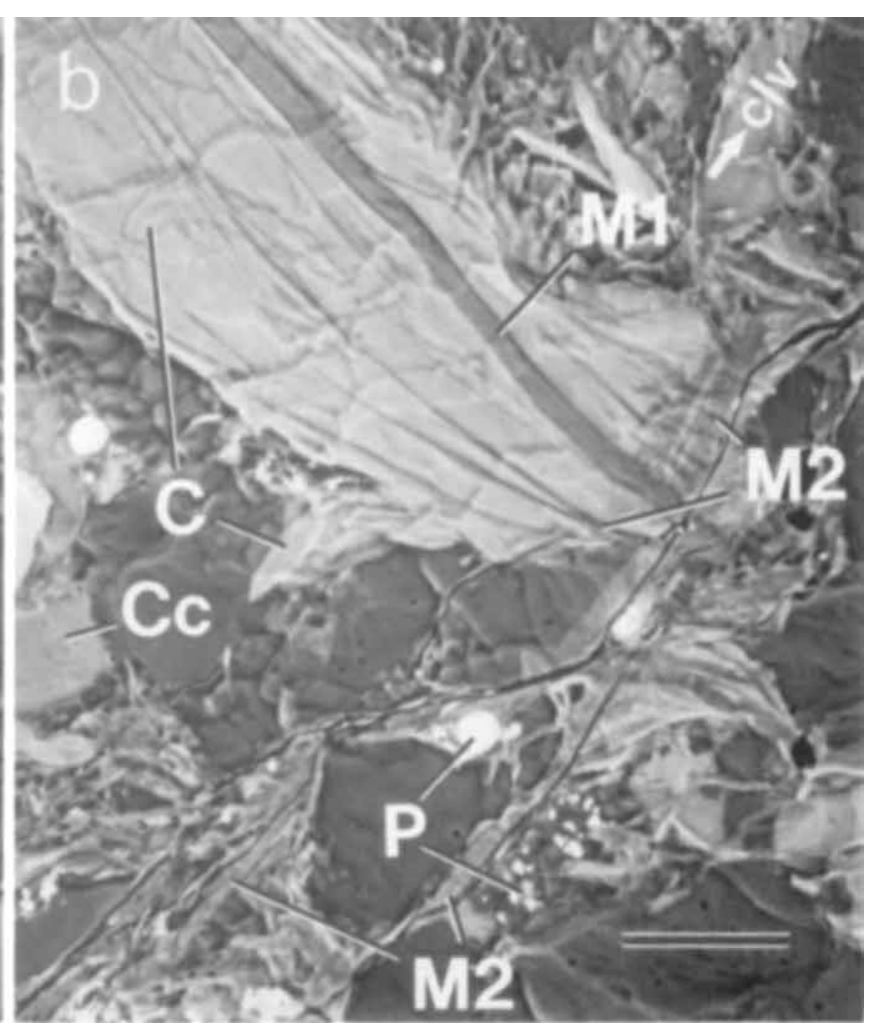

Fig. 13. Back-scattered electron images of two chlorite-muscovite stacks in epizonal sample R245. The direction of the spaced cleavage (clv) is indicated by white arrows. Small irregular grains with bright contrast and large irregular grains with dark grey contrast are rutile and quartz, respectively, in both (a) and (b). M1, relatively Fe-rich muscovite; M2, relatively Mg-rich muscovite; C, chlorite; Cc, calcite; $\mathrm{P}$, pyrite or pyrrhotite that were partially altered to magnetite. Scale bars $=20 \mu \mathrm{m}$. 


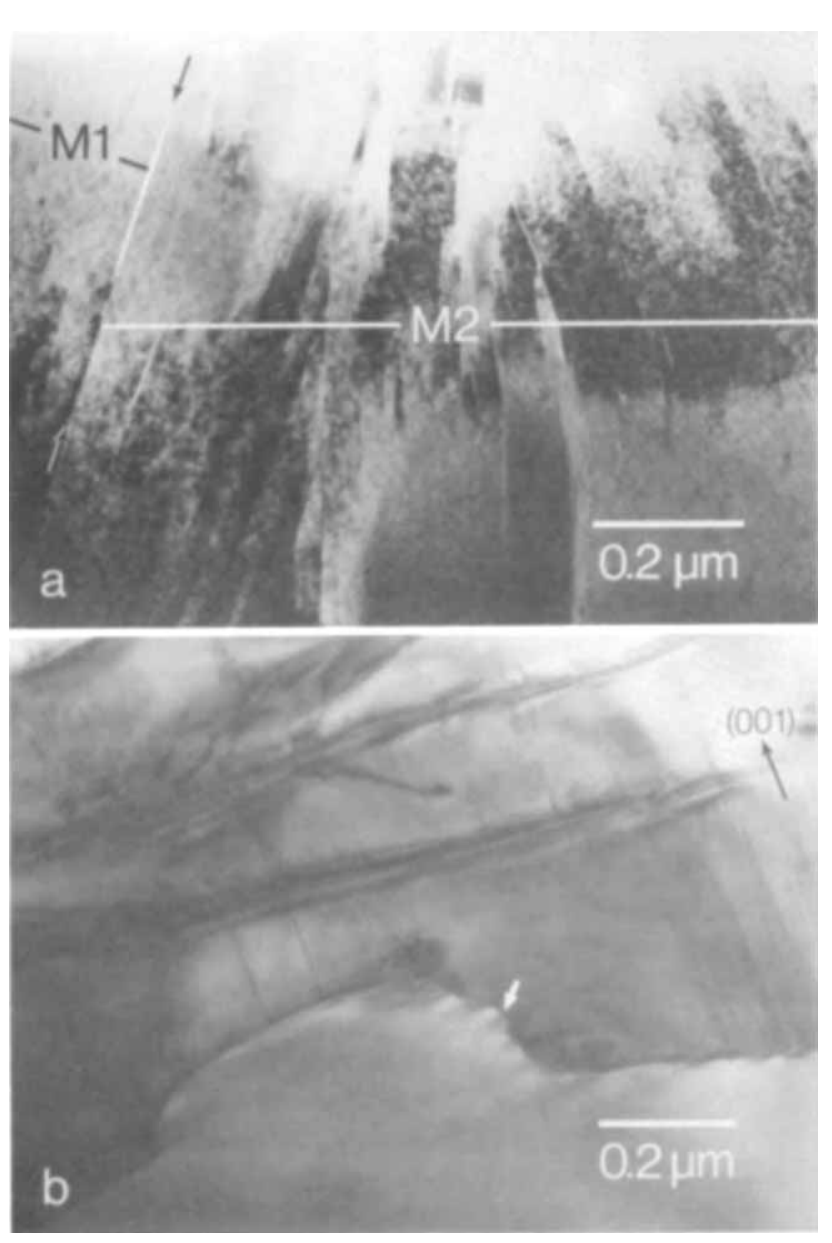

Fig. 14. (a) TEM image of relatively Fe-rich muscovite (MI) intergrown with partially deformed, relatively Mg-rich muscovite (M2) in a chlorite-muscovite stack in sample R245. The boundary between muscovite of different compositions is marked by two black arrows. (b) TEM image of chlorite in a chlorite-muscovite stack in sample R245 showing contrasting deformation features in the lower and upper regions.

micas. The corrensite-to-chlorite reaction assuming conservation of $\mathrm{Al}$ can be expressed as

$$
\begin{gathered}
1 \text { corrensite }+1 \text { titanite }+1.1 \mathrm{Fe}^{2+}+1.2 \mathrm{CO}_{2}+3.6 \mathrm{H}^{+} \\
=1.5 \text { chlorite }+1 \text { anatase }+1.2 \text { calcite }+4.7 \mathrm{SiO}_{2} \\
+2.1 \mathrm{Mg}^{2+}+0.4 \mathrm{~K}^{+}+0.4 \mathrm{Na}^{+}+0.1 \mathrm{H}_{2} \mathrm{O}
\end{gathered}
$$

where corrensite and titanite are those in Eq. (1), chlorite $=\left[\mathrm{Fe}_{5.1} \mathrm{Mg}_{4.3} \mathrm{Al}_{2.6}\right]\left[\mathrm{Si}_{5.4} \mathrm{Al}_{2.6}\right] \mathrm{O}_{20}(\mathrm{OH})_{16}$, anatase $=$ $\mathrm{TiO}_{2}$ and calcite $=\mathrm{CaCO}_{3}$. A significant amount of $\mathrm{K}$ is released through such a reaction. Potassium feldspar occurs in small amounts in the diagenetic rocks and may have provided $\mathrm{K}$ necessary for early formation of illite but it is absent in the higher grade rocks.

The occurrence of chlorite-muscovite (or phengite) stacks in the higher grade rocks is therefore inferred to have resulted from the diagenetic and metamorphic alteration of detrital biotite. Such a relation was also reported to occur in the shales and slates from the southern Appalachians by Weaver (1984) and in sandstones from Norway and France by Morad (1986) and Beaufort (1987). The occurrence of titanite in the diagenetic rocks and formation of calcite + quartz + anatase or rutile in the higher grade rocks (Eq. 2) are opposite to the prograde sequence of Ti-rich phases observed in the Salton Sea geothermal field (Yau et al., 1987). However, such a reaction is not only controlled by temperature but also by $f\left(\mathrm{CO}_{2}\right)$ and $f\left(\mathrm{O}_{2}\right)$. Increases of $f\left(\mathrm{CO}_{2}\right)$ occur commonly as a result of organic diagenesis (Surdam \& Crossey, 1985) and prograde changes of organic matter from the Gaspé sequence have been documented by Hesse \& Dalton (1991). The titanite and anatase or rutile are closely associated with altered detrital biotite and chlorite-muscovite stacks, respectively, suggesting a paragenetic relation between the Ti-rich phases and phyllosilicates which progressively evolved with increasing grade, as consistent with the origin of the chlorite-muscovite stacks at the expense of detrital biotite.

Phengitic $1 M_{\mathrm{d}}$ illite was observed to be intergrown with partially altered detrital biotite, but not with unaltered biotite. It commonly occurs as elongated, lenticular packets having curved, but well-defined boundaries in contact with adjacent altered biotite layers. The curved interfaces are defined by continuous primary or altered biotite layers, but curvature is accommodated by termination of illite layers. These relations imply that the illite formed as a filling of lenticular voids created by separation of (001) of layers of biotite or its alteration products, as concluded by $\mathrm{Li}$ et al. (1984) for stacks in shales of the Welsh Basin. Such filled fissures have commonly been observed in clay minerals in sandstones (Crowley, 1991, and references therein). The biotite often exhibits deformation features, and some of the illite-filled fissures are apparently also deformed, implying that those fissures were formed during or prior to deformation.

It is tentatively suggested that the $1 M_{\mathrm{d}}$ illite was formed by alteration of an early precursor such as kaolinite or smectite which filled open fissures along (001) interfaces created by stress, although direct formation of illite cannot be entirely ruled out, the biotite serving as a principal source of $\mathrm{K}$. The detrital biotite was subsequently altered to chloritic minerals, releasing $\mathrm{K}$, and the inferred precursor phase in the lenticular fissures was altered to form $1 M_{\mathrm{d}}$ illite as diagenesis proceeded. This model requires formation of additional quartz in the higher grade rocks, which is consistent with the increasing size and growth textures of quartz in BSE images and increasing intensity of quartz reflections relative to those of other phases in XRD patterns (not shown).

\section{Modification of chlorite-mica stacks}

The chlorite-muscovite stacks show a general trend of increasing average size with increasing grade. This suggests that the phyllosilicate stacks have not only been structurally and chemically altered but also affected by growth or overgrowth. Overgrowth is evidenced by the presence of compositionally different chlorite or muscovite packets in individual phyllosilicate stacks. In sample R245, 
some of the relatively $\mathrm{Mg}$-rich muscovite occurs in chlorite-muscovite stacks but most occurs in the matrix with (001) roughly parallel to the rock cleavage. The relatively $\mathrm{Fe}$-rich muscovite is largely restricted to chlorite-muscovite stacks. These relations imply that the relatively $\mathrm{Mg}$-rich muscovite is a later-formed phase. Individual grains may exhibit either abundant or few deformation features, but commonly have crystal outlines constrained by adjacent crystals. Bending of crystals against the edges of adjacent crystals also occurred. These features imply that overgrowth occurred before initiation of deformation and proceeded during deformation, as consistent with conclusions of others for similar textures (White \& Knipe, 1978; Brearley, 1990).

In contrast to the wide range of composition of chlorite found in lower grade rocks, epizonal chlorite has a rather uniform composition regardless of differences in texture (Jiang \& Peacor, 1994). This is inferred to have been caused by recrystallization of pre-existing chlorite and addition of a large amount of chlorite to the chlorite-mica stacks during epizonal metamorphism. The irregular interlocking textures between the stack chlorite and the surrounding matrix muscovite, quartz or other phases, the relatively large size of the chlorite-mica stacks compared with the low-grade equivalents, the recrystallization textures in the chlorite and the homogeneous composition of the chlorite indicate that significant recrystallization and crystallization of the epizonal chlorite in the chlorite-mica stacks must have occurred.

By contrast, the relatively Fe-rich muscovite locally shows deformation features but no indication of metamorphic recrystallization or crystallization. It is observed to be directly adjacent to the later-formed, relatively $\mathrm{Mg}$-rich muscovite that displays syntectonic growth textures. These relations suggest that the early formed muscovite was not as responsive as the chlorite to the epizonal metamorphic conditions, or that changes during metamorphism of the early formed muscovite occurred in a stepwise fashion involving dissolution (pressure solution) of the relatively $\mathrm{Fe}$-rich muscovite and crystallization of the later-formed, relatively Mg-rich muscovite in the matrix and in the opening fissures of chlorite-muscovite stacks.

The muscovite in the chlorite-muscovite stacks of the anchizonal rocks commonly occurs as two- or three-layer polytypes (presumably $2 M_{1}$ and $3 T$ ) and generally has an $\mathrm{Fe} /(\mathrm{Mg}+\mathrm{Fe})$ ratio greater than that of the matrix white mica. The matrix white mica displays $1 M_{\mathrm{d}}, 2 M_{1}$ and minor $1 M$ polytypism and has a composition ranging from that of illite to that muscovite. The differences between the less mature matrix and more evolved stack white micas are inferred to have been caused at least in part by the large local concentrations of $K$ available to the stack micas arising from alteration of biotite. A similar relation occurs in diagenetic rocks, where the phengitic $1 M_{\mathrm{d}}$ illite in biotite-bearing phyllosilicate stacks is generally more $\mathrm{K}$-rich than the matrix $1 M_{\mathrm{d}}$ illite. The association with biotite and potassium feldspar may affect the crystalchemical properties of white micas (see Kisch, 1983, for references).
The compositional variation of chlorite in the low-grade rocks is primarily due to a variety of formation processes including diagenetic/metamorphic crystallization from pore fluids, conversion of corrensite to chlorite and possibly alteration of berthierine and I/S (Jiang \& Peacor, 1994). In other words, the compositions of the anchizonal and diagenetic chlorite are largely controlled by heterogeneous local chemical environments. Nonetheless, evidence for syntectonic overgrowth of chlorite at the edges of chlorite-muscovite stacks is provided by the occurrence of tectonically deformed chlorite crystals at the edges of a chlorite-muscovite stack that have a composition different from that of the chlorite inside the chlorite-muscovite stack.

\section{Summary and geological implications}

This study demonstrates that detrital biotite can be a principal precursor to trioctahedral chloritic minerals and is the precursor of chlorite-muscovite stacks and much of the matrix clay in pelitic rocks. In the Gaspé sequence, detrital biotite was most likely derived from an ancient volcanic arc system, which is also implied by palaeocurrent data and volanic debris (Enos, 1969; Pickering, 1987; Jiang \& Peacor, 1994). Chlorite-rich low-grade pelitic rocks occurring in other marginal basins of similar tectonic setting, as represented by the Lower Palaeozoic rocks of Wales (Dimberline, 1986; Robinson \& Bevins, 1986; Milodowski \& Zalasiewicz, 1991), the Oslo region (Björlykke, 1974) and the southern Appalachians (Weaver, 1984), all of which also contain chloritemuscovite stacks, may have evolved through similar alteration processes.

Our data suggest that the detrital biotite was altered to form corrensite and chlorite through layer-by-layer replacement and by dissolution-transport-precipitation mechanisms, giving rise to formation of interstratified packets of chlorite, corrensite, biotite and illite, and aggregates of randomly orientated, corrensite-dominant flakes. The alteration products that occurred as thick phyllosilicate stacks or random mineral aggregates in the anchizonal and epizonal rocks evolved to form chloritemuscovite stacks through complex deformation, dissolution/crystallization and overgrowth. Fissures produced in altering biotite were filled with dioctahedral clays, and the stacks of immature trioctahedral and dioctahedral clays progressively transformed to packets of homogeneous chlorite and muscovite. Those clay minerals occurring in the matrix were progressively altered to form compositionally and structurally homogeneous crystals as consistent with an approach to equilibrium conditions.

The alteration of detrital biotite and alteration and formation of other phases have important mutual influences. The alteration of biotite gave rise to the formation of chloritic minerals, titanite and possibly some magnetite. The albitization of plagioclase provided necessary $\mathrm{Na}$ and $\mathrm{Ca}$ for the formation of corrensite from biotite. The trend of increasing $\mathrm{K}$ content with increasing grade in dioctahedral illite reflects initial formation from a $\mathrm{K}$-poor precursor such as smectite, with the necessary $\mathrm{K}$ being derived at least in part from detrital biotite and 
potassium feldspar during early diagenesis and subsequent dissolution-recrystallization of diagenetic illite and corrensite. The $\mathrm{Mg}^{2+}$ in Eq. (1) may not be necessary because Al may not be conserved but it perhaps was derived from trapped pore fluids or early dolomite or $\mathrm{Mg}$-bearing calcite.

The temperature at which the conversion of $\mathrm{C} / \mathrm{S}$ or corrensite to chlorite is completed varies from 120 to $270^{\circ} \mathrm{C}$, and trioctahedral smectite may be preserved at temperatures up to c. $200^{\circ} \mathrm{C}$ before $\mathrm{C} / \mathrm{S}$ can occur (Frey, 1987; Weaver, 1989; Bevins et al., 1991). The formation and loss of corrensite or $\mathrm{C} / \mathrm{S}$ occur at much lower temperatures in clastic sedimentary rocks than in metabasites or hydrothermally altered rocks (Frey, 1987; Weaver, 1989). Saponite, C/S and chlorite can occur in texturally different rocks that have experienced the same metamorphic or hydrothermal conditions (e.g. Schmidt, 1993). It is possible that local fluid chemistry that is generally governed by mineralogy and fluid/rock ratio have played a major role in many occurrences of $\mathrm{C} / \mathrm{S}$. The length of reaction time may also be important as hydrothermal alteration is generally short-lived and higher temperatures may be required for a mineral reaction to occur. An interesting aspect of the paragenetic relations in the Gaspé rocks is that the corrensite-magnetite-titanite assemblage in the diagenetic rocks was changed to the chlorite-pyrite-calcite-anatase (or rutile) assemblage in the higher grade rocks, the reaction involving titanite and magnetite being controlled by variations in $f\left(\mathrm{O}_{2}\right), f\left(\mathrm{~S}_{2}\right)$ and $f\left(\mathrm{CO}_{2}\right)$. Formation of corrensite or chlorite may be influenced by $f\left(\mathrm{O}_{2}\right)$ and $f\left(\mathrm{CO}_{2}\right)$ in a given environment (Meunier et al., 1988; Mexias et al., 1990; Huang et al., 1992). The observed mineral assemblages suggest that $f\left(\mathrm{O}_{2}\right)$ and $f\left(\mathrm{CO}_{2}\right)$ could be governed by the deconboxylation of organic matter (Surdam \& Crossey, 1985) and may have affected the formation and decomposition of corrensite in the Gaspé rocks.

A similar effect relating the availability of $\mathrm{K}$ occurs to the white micas in individual Gaspé samples. Those white micas that occur in fine-grained matrices are generally immature with larger $\mathrm{K}$ deficiencies, whereas those that have $\mathrm{K}$ inherited largely from detrital biotite and its alteration products evolve to relatively mature micas with compositions approaching that of idea muscovite. These relations suggest that the degree of diagenesis and low-temperature metamorphism that is commonly inferred from illite crystallinity index and occurrence of certain clay minerals may be a function of both temperature and local chemistry.

\section{ACKNOWLEDGEMENTS}

We are grateful to $R$. Hesse for providing samples. We thank D. Beaufort, E. J. Essene, B. A. van der Pluijm, L. $M$. Walter and an anonymous reviewer for their critical reviews. This work was supported by NSF grants EAR-88-17080 and EAR-91-04565 to D.R.P. The scanning transmission electron microscope and scanning electron microscope used in this study were acquired under NSF grants EAR-87-08276 and BSR-83-14092, respectively. This paper is contribution No. 501 from the Mineralogical
Laboratory, Department of Geological Sciences, The University of Michigan, Ann Arbor, MI 48109-1063, USA.

\section{REFERENCES}

AlDahan, A. A. \& Morad, S., 1986. Chemistry of detrital biotites and their phyllosilicate intergrowths in sandstones. Clay and Clay Minerals, 34, 539-548.

Altaner, S. P., 1989. Examination of models of smectite illitization. In: The Clay Minerals Society 26th Annual Meeting. Sacramento, California, p. 13 (abstract).

Banfield, J. F. \& Eggleton, R. A., 1988. Transmission electron microscope study of biotite weathering. Clays and Clay Minerals, 36, 47-60.

Beaufort, D., 1987. Interstratified chlorite/smectite ("metamorphic vermiculite") in the Upper Precambrian greywackes of Rouez, Sarthe, France. In: Proceedings of the International Clay Conference, Denver, 1985 (eds Schultz, L. G., van Olphen, H. \& Mumpton, F. A.), pp. 59-65. The Clays Minerals Society, Bloomington, Indiana.

Bettison, L. A. \& Schiffman, P., 1988. Compositional and structural variations of phyllosilicates from the Point Sal ophiolite, California. American Mineralogist, 73, 62-76.

Bettison-Varga, L., Mackinnon, I. D. R. \& Schiffman, P., 1991. Integrated TEM, XRD and electron microprobe investigation of mixed-layer chlorite-smectite from the Point Sal ophiolite California. Journal of Metamorphic Geology, 9, 697-710.

Beutner, E. C., 1978. Slaty cleavage and related strain in Martinsburg slate, Delaware Water Gap, New Jersey. American Journal of Science, 278, 1-23.

Bevins, R. E., Robinson, D. \& Rowbotham, G., 1991 Compositional variations in mafic phyllosilicates from regional low-grade metabasites and application of the chlorite geothermometer. Journal of Metamorphic Geology, 9, 711-721.

Bjölykke, K., 1974. Geochemical and mineralogical influence of Ordovician island arcs on epicontinental clastic sedimentation. A study of Lower Palacozoic sedimentation in the Oslo Region, Norway. Sedimentology, 21, 251-272.

Boles, J. R. \& Franks, S. G., 1979. Clay Diagenesis in Wilcox sandstones of southwest Texas: implication of smectite diagenesis on sandstone cementation. Journal of Sedimentary Petrology, 49, 55-70.

Brearley, A. J., 1990. Transmission electron microscopy of phyllosilicate minerals from low-grade chloritoid-bearing rocks, North Wales. In: Electron-Optical Methods in Clay Science (eds Mackinnon, I. D. R. \& Mumpton, F. A.), pp. 135-152. The Clay Minerals Society, Boulder, Colorado.

Brigatti, M. F. \& Poppi, L., 1984. Crystal chemistry of corrensite: a review. Clays and Clay Minerals, 32, 391-399.

Claeys, P. F. \& Mount, J. F., 1991. Diagenetic origin of carbonate, sulfide, and oxide inclusions in biotites of the Great Valley Group (Cretaceous), Sacramento Valley, California. Journal of Sedimentary Petrology, 61, 719-731.

Craig, J., Fitches, W. R. \& Maltman, A. J., 1982. Chlorite-mica stacks in low-strain rocks from central Wales. Geological Magazine, 119, 243-256.

Crowley, S. F., 1991. Diagenetic modification of detrital muscovite: an example from the Great Limestone Cyclothem (Carboniferous) of Co. Durham, UK. Clay Minerals, 26, 91- 103 .

Dimberline, A. J., 1986. Electron microscope and microprobe analysis of chlorite-mica stacks in the Wenlock turbidites, mid Wales, U.K. Geological Magazine, 123, 299-306.

Eggleton, R. A. \& Banfield, J. F., 1985. The alteration of granitic biotite to chlorite. American Mineralogist, 70, 902-910.

Enos, P., 1969. Cloridorme Formation, Middle Ordovician flysch, northern Gaspé Peninsula, Quebec. The Geological Society of America, Special Paper, 117.

Frey, M., 1987. Low Temperature Metamorphism. Chapman and Hall, New York.

Gregg, W. J., 1986. Deformation of chlorite-mica aggregates in cleaved psammitic and pelitic rocks from Islesboro, Maine, U.S.A. Journal of Structural Geology, 8, 59-68. 
Hesse, R. \& Dalton, E., 1991. Diagenetic and low-grade metamorphic terranes of Gaspé-Peninsula related to geological structure of the Taconian and Acadian orogenic belts, Quebec Appalachians. Journal of Metamorphic Geology, 9, 775-790.

Huang, W. L., Longo, J. M., Otten, G. A. \& Brown, R. W. 1992. Effect of $X_{C_{2}}$ and $f_{O}$ on smectite vs. chlorite formation during aluminosilicate/carbonate reactions: experimental studies. In: The 29th International Geological Congress, Kyoto, Japan, Vol. 3, p. 100 (abstract).

Inoue, A., 1985. Chemistry of corrensite: a trend in composition of trioctahedral chlorite/smectite during diagenesis. Journal of the College of Arts and Science, Chiba University, B-18, 69-82.

Jiang, W.-T., 1993. Diagenesis and Very Low-Grade Metamorphism of Pelitic Rocks from the Gaspé Peninsula, Quebec. Unpubl. PhD Dissertation, University of Michigan, Ann Arbor, Michigan.

Jiang, W.-T. \& Peacor, D. R., 1993. Formation and modification of metastable intermediate sodium potassium mica, paragonite and muscovite in hydrothermally altered metabasites from northern Wales. American Mineralogist, 78, 782-793.

Jiang, W.-T. \& Peacor, D. R., 1994. Prograde transitions of corrensite and chlorite in low-grade pelitic rocks from the Gaspé Peninsula, Ouebec. Clays and Clay Minerals, in press.

Jiang, W.-T., Peacor, D. R. \& Slack, J. F., 1992. Microstructures, mixed layering, and polymorphism of chlorite and retrograde berthierine in the Kidd Creek massive sulfide deposit, Ontario Clays and Clay Minerals, 40, 501-514

Kisch, H. J., 1983. Mineralogy and petrology of burial diagenesis (burial metamorphism) and incipient metamorphism in clastic rocks. In: Diagenesis in Sediments and Sedimentary Rocks 2 (eds Larsen, G. \& Chilingar, G. V.), pp. 289-493. Elsevier, Amsterdam.

Kisch, H. J., 1990. Calibration of the anchizone: a critical comparison of illite 'crystallinity' scales used for definition. Journal of Metamorphic Geology, 8, 31-46.

Li, G., Peacor, D. R., Merriman, R. J., Robets, B. \& van der Pluijm, A., 1994. TEM and AEM constraints on the origin and significance of chlorite-mica stacks in slates: an example from central Wales, U.K. Journal of Structural Geology, in press

Meunier, A., Clement, J.-Y., Bouchet, A. \& Beaufort, D., 1988. Chlorite-calcite and corrensite-dolomite crystallization during two superimposed events of hydrothermal alteration in "Les Crêtes" granite, Vosges, France. Canadian Mineralogist, 26, 413-422.

Meunier, A., Inoue, A. \& Beaufort, D., 1991. Chemiographic analysis of trioctahedral smectite-to-chlorite conversion series from the Ohyu caldera, Japan. Clays and Clay Minerals, 39, $409-415$.

Mexias, A., Formoso, M., Meunier, A. \& Beaufort, D., 1990 Composition and crystallization of corrensite in volcanic and pyroclastic rocks of Hilário Formation, (RS) Brazil. In: Proceedings of the 9 th International Clay Conference, Strasbourg, 1989 (eds Farmer, V. C. \& Tardy, Y.), Sciences Géologiques, Mémoire, 88, 135-143.

Milodowski, A. E. \& Zalasiewicz, J. A., 1991. The origin and sedimentary, diagenetic, and metamorphic evolution of chlorite-mica stacks in Llandovery sediments of central Wales, U.K. Geological Magazine, 128, 263-278.

Moore, D. M. \& Reynolds, R. C., 1989. X-ray Diffraction and the Identification and Analysis of Clay Minerals. Oxford University Press, New York.

Morad, S., 1986. Mica-chlorite intergrowths in very low-grade metamorphosed sedimentary rocks from Norway. Neues Jahrbuch für Mineralogie, Abhandlungen, 154, 271-287.

Morad, S. \& AlDahan, A. A., 1986. Diagenetic alteration of detrital biotite in Proterozoic sedimentary rocks from Sweden. Sedimentary Geology, 47, 95-107.

Olives, J. \& Amouric, M., 1984. Biotite chloritization by interlayer brucitization as seen by HRTEM. American Mineralogist, 69, 869-871.

Pickering, K. T., 1987. Deep-marine foreland basin and forearc sedimentation: a comparative study from the Lower Palacozoic northern Appalachians, Quebec and Newfoundland. In: Marine
Clastic Sedimentology (eds Leggett, J. K. \& Zuffa, G. G.), pp. 190-211. Graham and Trotman, London.

Roberts, B. \& Merriman, R. J., 1990. Cambrian and Ordovician metabentonites and relevance to the origins of associated mudrocks in the northern sector of the lower Palaeozoic Welsh marginal basin. Geological Magazine, 12, 31-43.

Robinson, D. \& Bevins, R. E., 1986. Incipient metamorphism in the Lower Palaeozoic marginal basin of Wales. Journal of Metamorphic Geology, 4, 101-113.

Robinson, D., Bevins, R. E. \& Rowbotham, G., 1993. The characterization of mafic phyllosilicates in low-grade metabasalts from eastern North Greenland. American Mineralogist, 78, $377-390$.

Schmidt, S. Th., 1993. Regional and local patterns of low-grade metamorphism in the North Shore Volcanic Group, Minnesota, USA. Journal of Metamorphic Geology, 11, 401-414.

Shau, Y.-H. \& Peacor, D. R., 1992. Phyllosilicates in hydrothermally altered basalts from DSDP hole 504B, leg 83 a TEM and AEM study. Contributions to Mineralogy and Petrology, 112, 119-133.

Shau, Y.-H., Peacor, D. R. \& Essene, E. J., 1990. Corrensite and mixed-layer chlorite/corrensite in metabasalt from northern Taiwan: TEM/AEM, EPMA, XRD, and optical studies. Contributions to Mineralogy and Petrology, 105, 123-142.

St. Julien, P. \& Hubert, C., 1975. Evolution of the Taconian orogen in the Quebec Appalachians American Journal of Science, 275-A, 337-362.

Suk, D., Peacor, D. R. \& Van der Voo, R., 1990. Replacement of pyrite framboids by magnetite in limestone and implications for paleomagnetism. Nature, 345, 611-613.

Surdam, R. C. \& Crossey, L. J., 1985. Mechanisms of organic/inorganic interactions in sandstone/shale sequences. In: Relationship of Organic Matter and Mineral Diagenesis (eds Gautier, D. L., Kharaka, Y. K. \& Surdam, R. C.), pp. 177-232. Society of Economic Paleontologists and Mineralogists, Tulsa, Oklahoma.

Vali, H. \& Hesse, R., 1992. Identification of vermiculite by transmission electron microscopy and X-ray diffraction. Clay Minerals, 27, 185-192.

Van der Pluijm, B. A. \& Kaars-Sijpesteijn, C. H., 1984. Chlorite-mica aggregates: morphology, orientation, development and bearing on cleavage formation in very low-grade rocks. Journal of Structural Geology, 6, 399-407.

Weaver, C. E., 1984. Shale-Slate Metamorphism in Southern Appalachians, Elsevier, New York.

Weaver, C. E., 1989. Clays, Muds, and Shales. Elsevier, Amsterdam.

Weber, K., 1981. Kinematic and metamorphic aspects of cleavage formation in very low-grade metamorphic slates. Tectonophysics, 78, 291-306.

White, S. H. \& Knipe, R. J., 1978. Microstructure and cleavage development in selected slates. Contributions to Mineralogy and Petrology, 66, 165-174.

White, S. H., Huggett, J. M. \& Shaw, H. F., 1985. Electron-optical studies of phyllosilicate intergrowths in sedimentary and metamorphic rocks. Mineralogical Magazine, 49, 413-423.

Woodland, B. G., 1985. Relationship of concretions and chlorite-muscovite porphyroblasts to the development of domainal cleavage in low-grade metamorphic deformed rocks from north-central Wales, Great Britain. Journal of Structural Geology, 7, 205-215

Yau, Y. C., Anoitz, L. M., Essene, E. J. \& Peacor, D. R., 1984. Phlogopite-chlorite reaction mechanisms and physical conditions during retrograde reactions in the Marble Formation, Franklin, New Jersey. Contributions to Mineralogy and Petrology, 88, 299-306.

Yau, Y. C., Peacor, D. R. \& Essene, E. J., 1987. Authigenic anatase and titanite in shales from the Salton Sea Geothermal Field, California. Neues Jahrbuch für Mineralogie, Monatshefte, H.10, $441-452$.

Received 16 July 1993; revision accepted 6 June 1994 